\title{
The Limits of Delignification in Kraft Cooking
}

\author{
Elisabet Brännvall \\ The perspective of the article is to explore kraft cooking at the limits of \\ delignification, i.e. what degree of delignification is needed to obtain fibre \\ liberation and what is the maximum degree of delignification possible in \\ the kraft pulping stage. The reasons for the quite narrow boundaries for \\ sufficient and maximum delignification are explained, and the differences \\ between the behaviour of hardwood and softwood kraft pulping are \\ clarified.
}

Keywords: Alkaline hydrolysis; Cooking parameters; Delignification; Effective alkali; Impregnation; Hardwood; Modified kraft cooking; Peeling; Softwood; Stopping

Contact information: Innventia, Box 56104, 11486 Stockholm, Sweden;

* Corresponding author: elisabet.brannvall@innventia.com

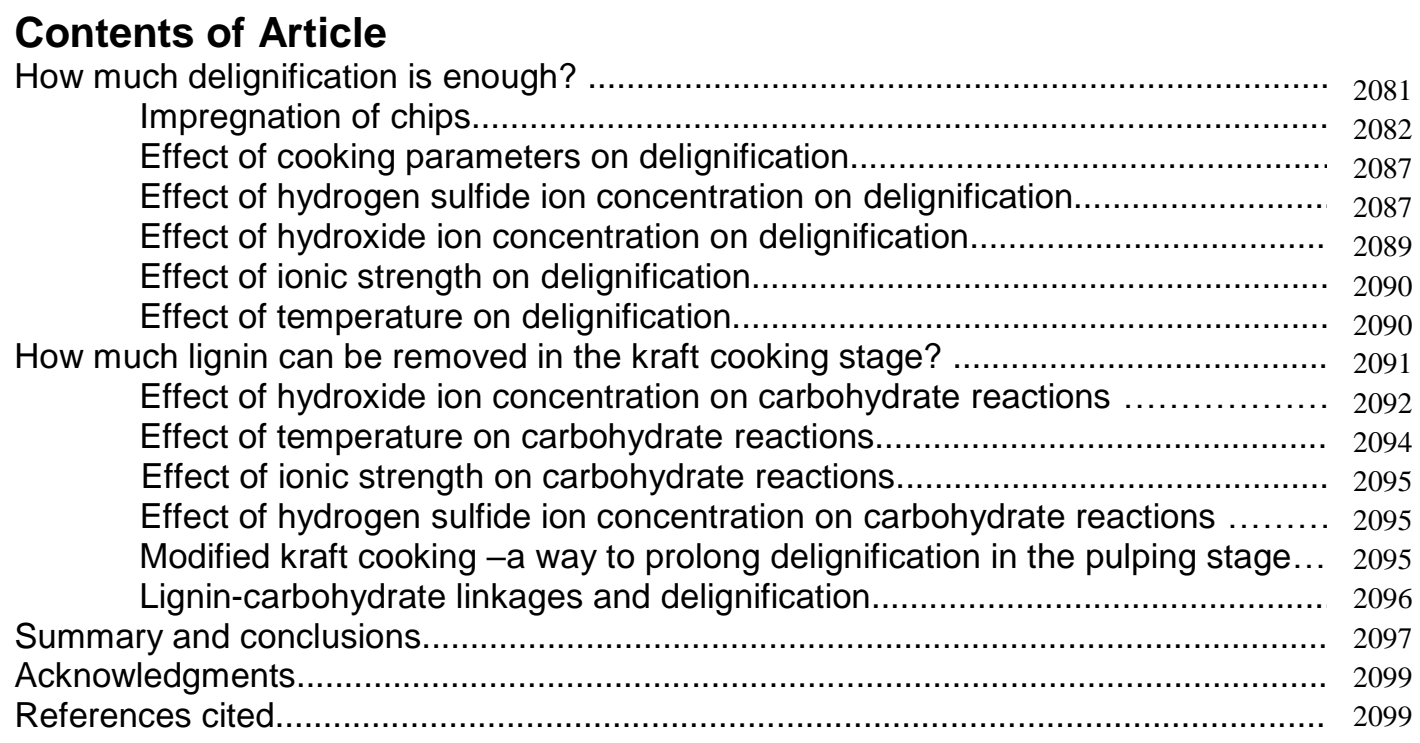

\section{HOW MUCH DELIGNIFICATION IS ENOUGH?}

In chemical pulping for paper-grade pulp, the main objective of the cooking stage is to liberate the fibres in the biomass. This is accomplished by chemically degrading and dissolving the components in the middle lamellae, i.e. the interface between fibres. The point at which wood fibres are liberated from the wood matrix occurs when the wood can be defibrated without the need of mechanical energy. Industrially, the pressure release when the digester is emptied of the delignified wood is sufficient for defibration to take place. The major component in the middle lamellae is lignin, the concentration being approximately 50\%, reaching to as much as $90 \%$ in the intersection between four tracheids, while the secondary wall has a lignin concentration of approximately 25\% (Saka et al. 1983; Fengel and Wegener 1984; Chiang et al. 1989). Chemical fibre liberation is thus achieved by delignifying wood, and this is accomplished by employing 
chemicals able to degrade and dissolve lignin. Around a quarter of the total amount of lignin in wood is located in the middle lamellae, which suggests that the lowest degree of delignification sufficient for fibre liberation would be around $25 \%$. However, in reality more than $80 \%$ of the lignin originally present in wood needs to be removed before the point of chemical fibre liberation has been reached. The reasons for the large discrepancy between the theoretically least degree of delignification needed and the actual degree obtained in practice result from how delignification proceeds at a macroscopic level (within chips) and at a microscopic level (within fibres).

\section{Impregnation of Chips}

On a fibre level, the first criterion towards fibre liberation is for cooking chemicals to reach the middle lamellae. Cooking liquor introduced to wood chips initially penetrates through capillaries that have been revealed in the chipping process (Fig. 1). In softwood, these are the lumen openings, and in hardwood these are mainly the vessel elements (Wardrop and Davies 1961; Wardrop 1963). Moreover, ray cell channels make it possible for radial liquid penetration into wood chips (Wardrop and Davies 1961). Also, resin canals provide openings for longitudinal liquor flow.

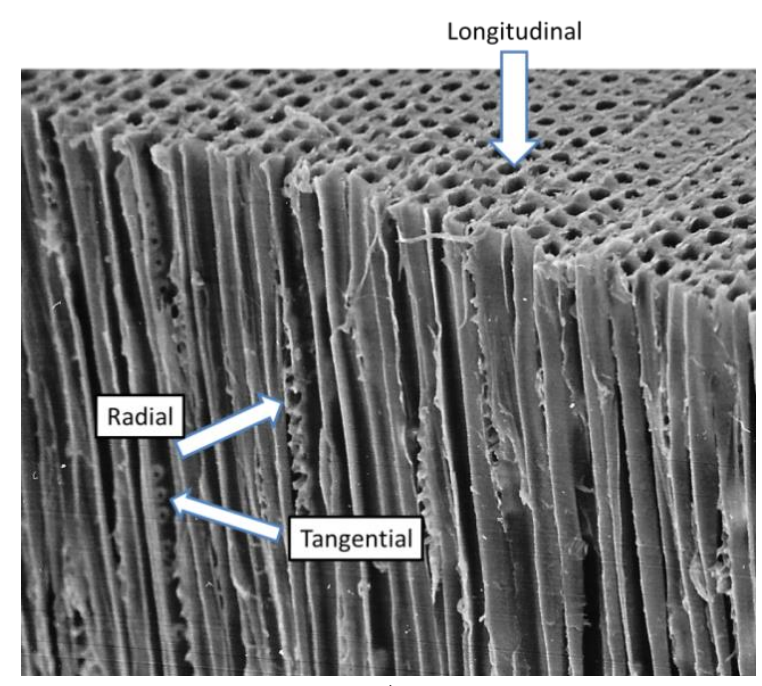

a)

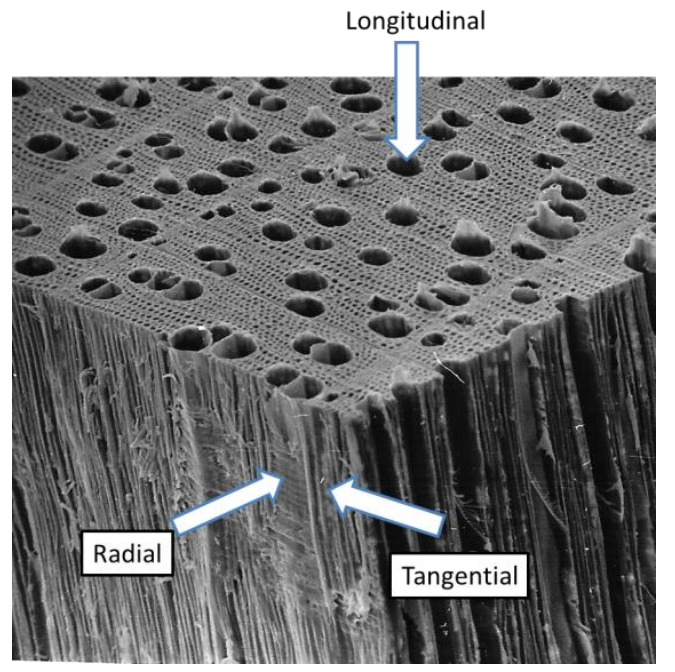

b)

Fig. 1. a) Softwood. The surface shows the lumen openings of the tracheids, and the tangential cut shows the lumen capillaries. Inside the lumen capillaries, the pith openings connect one tracheid with the adjacent tracheid. Ray cells seen between some fibres permit radial flow into the wood. b) Hardwood (birch). Liquor penetration takes place mainly through the large vessels but also through the much smaller cavities within the libriform cells. Radial flow occurs through the scalariform perforation plates in the vessel cell walls.

When the exposed capillaries have been filled, continued liquor flow in hardwood takes place from vessel elements to libriform cells through the scalariform perforation plates. In softwood, liquid flow occurs through bordered pits in the softwood cell wall (Fig. 2a). Bordered pits are arranged in pairs, such that one pit in the softwood fibre wall is connected to a pit opening in the adjacent fibre. As can be seen in Fig. 2b, the passage through the pits brings the cooking chemicals in direct contact with the middle lamellae (Wardrop 1963). 


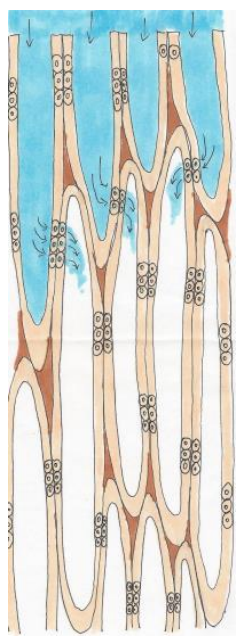

a)

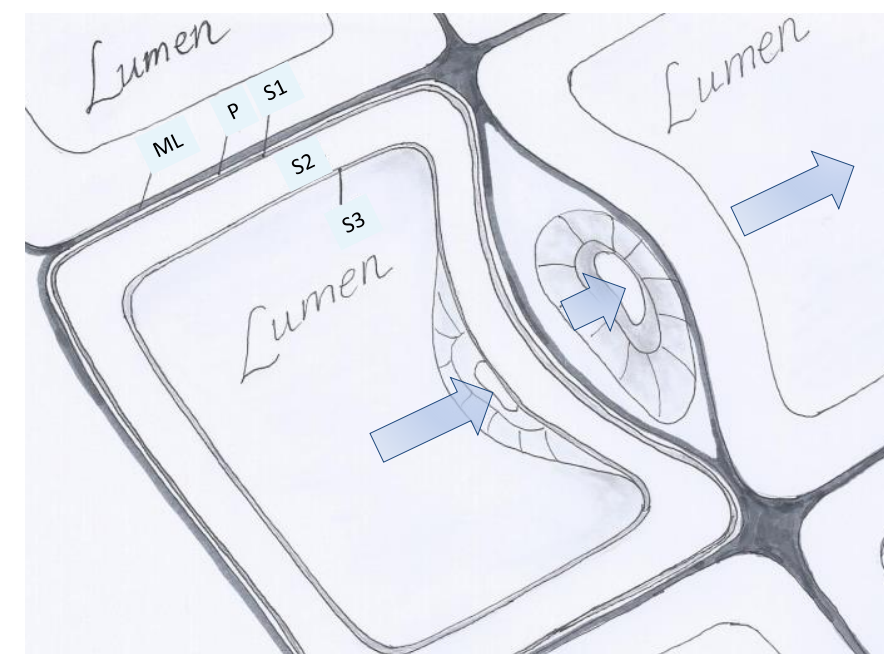

b)

Fig. 2. a) Schematic figure of liquid flow through the open lumen at the chip surface followed by liquid entering the adjacent fibre through pit openings in the fibre wall. b) Liquid flow (blue arrows) from one lumen cavity to the next lumen of the adjacent fibre through the bordered pits. MLmiddle lamellae, P-primary wall, S1-transition lamellae, S2-secondary wall, S3-tertiary wall. Drawings by the author. Figure $2 \mathrm{~b}$ is inspired by Figure 11 in the published Academic Lecture held by Coté (1981).

When all empty capillaries have been filled, liquid penetration comes to an end and transport of cooking chemicals continues by diffusion. Note that if the cooking liquor reaches a fibre with its lumen filled with chip moisture, transport of cooking chemicals will take place by diffusion. At a moisture content in fresh chips of around $50 \%$, approximately $45 \%$ of the voids are filled with chip moisture.

In kraft cooking, the active chemical species are hydroxide and hydrogen sulfide ions, and the environment is highly alkaline, with $\mathrm{pH}$ levels ranging from 14 down to 11 . At these high $\mathrm{pH}$ levels, diffusion rates of chemicals are quite similar in longitudinal and radial directions, as alkali will swell the wood. At the $\mathrm{pH}$ prevailing in kraft cooking, carboxylic, phenol, and hydroxyl groups are deprotonated. The pKa for carboxyl groups in hemicelluloses is approximately 3.4 (Laine et al. 1994) and in pectin 3 to 3.5 (Kohn and Kovac 1978). The $\mathrm{pKa}$ for phenolic groups in lignin ranges from approximately 6 to 11 (Ragnar et al. 2000). Higher temperature, molecular weight, and ionic strength leads to decreased degree of dissociation of phenolic groups (Norgren and Lindström 2000). For hydroxyl groups in cellulose and hemicelluloses chains, the $\mathrm{pKa}$ has been determined to be approximately 14 to 15 (Saric and Schofield 1946; Pennings and Prins 1962).

Deprotonation leads to electrostatic repulsion and swelling of the fibre wall and enlarges the paths for ionic movement. The hydroxide ions will split off acetyl groups, and deacetylation is one of the main alkali-consuming reactions during kraft cooking. Acetyl groups can form strong hydrogen bonds with carboxyl groups, so deacetylation also increases the paths available for diffusion (Sjöström et al. 1965; Zanuttini et al. 1998; Inalbon and Zanuttini 2008; Inalbon et al. 2009a; Montagna et al. 2013). For fibre liberation, it would be desired if the lignin located in the middle lamellae would be specially targeted for degradation reactions and dissolution. However, as pointed out earlier, cooking chemicals have a complicated path to travel before reaching the middle lamellae either by liquor flow through the pits or by diffusion through the fibre wall. As 
seen in Fig. 3, as much as 40 to $50 \%$ of the total lignin content has been removed before substantial delignification of the middle lamellae and cell corners will take place (Procter et al. 1967; Yang and Goring 1978; Saka et al. 1982).

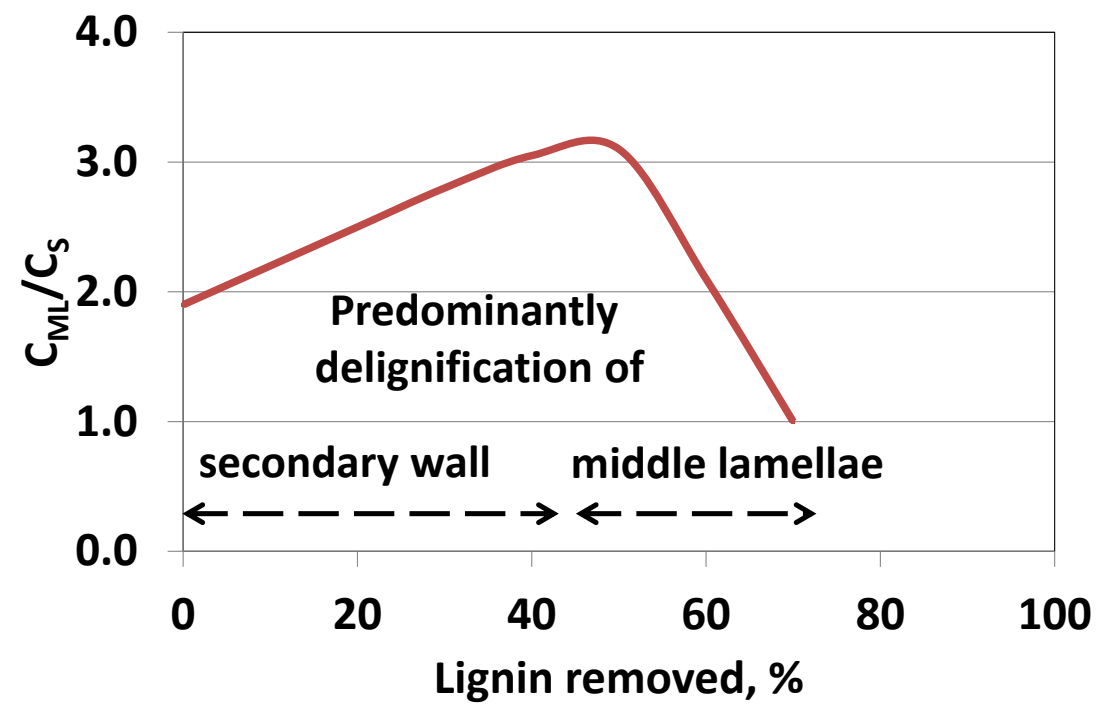

Fig. 3. The ratio between the concentration of lignin in the middle lamellae $\left(C_{\mathrm{ML}}\right)$ and in the secondary wall $(C s)$ as a function of lignin removed from spruce fibres. Adapted from Procter et al. (1967)

The cell corners are the last part of the middle lamellae to be delignified (Procter et al. 1967). It has been suggested that removal of hemicelluloses makes the secondary wall more accessible by increased porosity, which would facilitate removal of lignin from this part (Wood et al. 1972). Although a correlation between pore size and molecular weight of dissolved lignin has been demonstrated (Ahlgren et al. 1971), experiments strongly indicate that the primary wall and S1 layer are not posing physical barriers for lignin dissolution, but the difference in delignification rate between secondary wall and middle lamellae is due to differences in lignin structure (Kerr and Goring 1976; Whiting and Goring 1982). The lignin in the middle lamellae of softwoods is highly condensed, making it less reactive (Chiang et al. 1989; Liitiä et al. 2000). Secondary wall lignin contains twice as much phenolic hydroxyl groups as the middle lamellae (Yang and Goring 1978; Hardell et al. 1980; Whiting and Goring 1982). Consequently, the structure of the lignin in the secondary wall makes it preferentially removed compared to the lignin in the middle lamellae.

Contrary to softwood lignin, which practically only consists of guaiacyl lignin units $(\mathrm{G})$, hardwood lignin also contains syringyl lignin units $(\mathrm{S})$. In the middle lamellae, guaiacyl units (G) dominate (Fergus and Goring 1970; Kolar et al. 1982; Saka et al. 1983; Saka 2000; Reza et al. 2015).

Since syringyl units are more reactive in kraft delignification reactions, the secondary wall is delignified faster than the middle lamellae (Fergus and Goring 1969; Sarkanen 1971; Chang and Sarkanen 1973; Chiang and Funaoka 1990; Ibarra et al. 2007). In the temperature range 110 to $140{ }^{\circ} \mathrm{C}, 1.4 \mathrm{~S}$ units are removed for every $\mathrm{G}$ unit. At temperatures above $140{ }^{\circ} \mathrm{C}, 3 \mathrm{~S}$ units are removed for every $\mathrm{G}$ (Chiang and Funaoka 1990). The residual lignin is essentially only composed of G (Chiang and Funaoka 1990). 


\section{Defibration Point}

On a larger scale, the entire chip has to be sufficiently impregnated with cooking chemicals when delignification reactions start at elevated temperatures. Insufficient impregnation leads to inhomogeneous delignification, with the chip surface being delignified to a higher extent than the chip core, which in the worst case may remain unreacted or insufficiently reacted. These inadequately delignified chip cores are called shives or rejects. Industrially, the fibre liberation point or defibration point is related to the amount of shives in the pulp obtained after cooking. Commonly, the defibration point is set to a shives content of $1 \%$ on wood. The defibration point is not fixed at a certain degree of delignification but depends on conditions applied in the kraft pulping. Generally, it is in the kappa number range of 35 to 50 for softwood. For hardwoods the kappa number range for the defibration point is between 15 and 35 (Fig. 4).

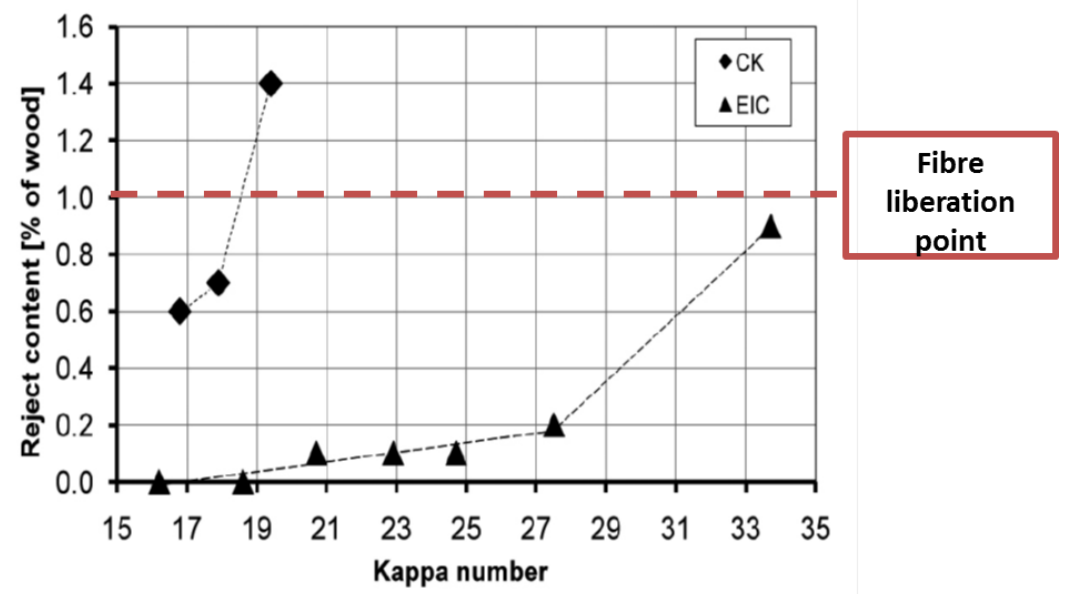

Fig. 4. The defibration point (or fibre liberation point) for conventional kraft cooking (CK) and extended impregnation kraft cooking (EIC) of eucalyptus (Wedin et al. 2010)

The amount of shives is a direct measure of how homogeneously the chips have been delignified. In order to obtain homogeneous delignification, a sufficient amount of active cooking chemicals need to have been transported to the chip cores. The impregnation of chips with cooking chemicals can be described by the shrinking core reaction model (Zanuttini et al. 2000, 2003, 2005; Inalbon et al. 2009b), as illustrated in Fig. 5. As alkali enters the wood, hydroxide ions are consumed in reactions with wood components. The impregnated part of the wood chip is a swollen gel, while the unreacted core has not yet been reached by alkali. The unreacted core and the swollen shell are separated by the reaction zone, where cleavage of acetyl groups and formation of phenolate and carboxylate ions takes place, consuming alkali. The diffusion rate of alkali into the chip is determined by paths available for ion transport, concentration of ions, and temperature. However, diffusion of alkali affects the ion transport properties of wood by swelling the fibre wall and the alkali concentration is affected by the reactions with wood components (Inalbon et al. 2011). Swelling of wood improves ion mobility, and it can be assumed that diffusion is not restricted in the swollen shell (Inalbon and Zanuttini 2008; Inalbon et al. 2009a). The consumption of alkali affects the concentration gradient and consequently the diffusion rate. It is thus important that the initial effective alkali concentration is high enough to provide enough alkali for both consumption in the reactions taking place during impregnation as well as to supply sufficient amount of alkali through the entire chip at the start of delignification reactions. 


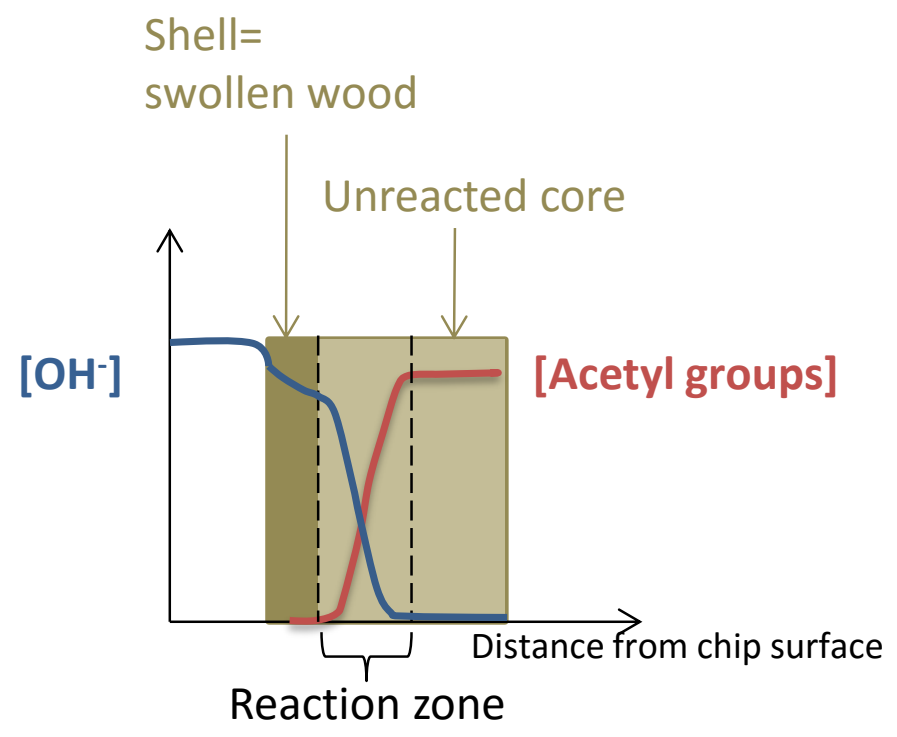

Fig. 5. Schematic figure showing impregnation of wood using the shell-core model. The shell consists of the alkali impregnated swollen wood, and the core is the yet unimpregnated chip centre. Shell and core are separated by the reaction zone where alkali reacts with wood components. The blue and red curves show the hydroxide ion concentration and amount of acetyl groups, respectively, through the chip in the thickness direction.

All measures to decrease shives content and move the defibration point to higher kappa number involve a more homogeneous impregnation of the chips prior to delignification. For hardwood, the point of fibre liberation is also affected by the S/G ratio. The higher the $S / G$ ratio in the original wood, the lower the kappa number at which the defibration point is reached (Colodette and Borges Gomes 2014).

The amount of shives is reduced and the fibre liberation point is achieved at higher kappa number when:

- the chips are presteamed before addition of cooking liquor, compared to no presteaming (Hartler and Östberg 1959; Kleinert 1964; Read et al. 1969; Malkov et al. 2002; Malkov et al. 2003)

- chips have cracks (Sainio 2000)

- an impregnation stage is implemented before the cooking stage (Ahlgren and Olausson 1973; Tikka and Kovasin 1990; Hultholm 2004; Wedin et al. 2010)

- impregnation time is increased (Tolonen et al. 2010)

- cooking temperature is decreased (Bäckström and Jensen 2001)

- enough alkali is available in the impregnation to avoid alkali depletion (Gullichsen et al. 1995; Santiago et al. 2008)

- overpressure is employed in impregnation (Malkov et al. 2002)

- chip thickness is reduced (Hartler and Onisko 1962; Gullichsen et al. 1992; Dang and Nguyen 2008)

- chip thickness is homogeneous (Tyler and Edwards 1982). More rejects are produced if 5\% over-thick chips are mixed with chips having a thickness of $3 \mathrm{~mm}$ than if all chips are over-thick $(12 \mathrm{~mm})$ 
Nevertheless, even with these measures to decrease the degree of delignification needed for fibre liberation, a large portion of the lignin is removed before the defibration point is reached. Fergus and Goring (1969) contemplated the possibility of delignifying the middle lamellae faster than the secondary wall. Since the lignin structure evidently is quite different in these morphological areas, they proposed that a solvent more selective towards middle lamellae lignin should be used. The suggestion by Yang and Goring was to use reagents more reactive with non-phenolic lignin or a non-polar solvent (Yang and Goring 1978).

\section{Effect of Cooking Parameters on Delignification}

A number of parameters affect the kraft cook, from charge of active cooking chemicals to pulping equipment configuration. In the sections below, the description of the effect on pulping is limited to temperature and different parameters pertaining to the chemical environment.

\section{Effect of Hydrogen Sulfide Ion Concentration on Delignification}

The lignin reactions taking place during chemical fibre liberation can be seen as reactions leading to either degradation or condensation of lignin as the hydroxide ions, hydrogen sulfide ions, and carbanions compete to react with lignin (Gierer 1980). At higher concentrations of $\mathrm{HO}^{-}$and $\mathrm{HS}^{-}$, the degradation reactions will be favored. The delignification rate is significantly higher in kraft cooks compared to soda cooks, in which only sodium hydroxide ions are employed as active cooking chemical. $\mathrm{HS}^{-}$ increases the rate of lignin degradation by specifically promoting cleavage of $\beta$-aryl-ether linkages in phenolic units in the lignin molecule. The largest effect on delignification rate is when sulfidity is increased from 0 to $10 \%$, which calculated as [HS ${ }^{-}$is from 0 to approximately 0.07 mol/L (Hart and Strapp 1948; Legg and Hart 1960; Aurell 1963; Rydholm 1965). At higher hydrogen sulfide ion concentrations, the increase in delignification rate is less pronounced (Legg and Hart 1960; Aurell 1963; Lindgren and Lindström 1996). The consumption of hydrogen sulfide ions during a kraft cook is significantly lower compared to the consumption of hydroxide ions (Bäckström and Jensen 2001). Generally, the concentration decreases only 20 to $35 \%$ as hydrogen sulfide after reaction with $\beta$-aryl ether bonds will to some extent be regenerated. After cleaving a $\beta$-aryl ether bond, the sulfide is covalently bound to the lignin as an episulfide unit, which subsequently is released as elemental sulfur into the cooking liquor. The elemental sulfur will be oxidized to polysulfide, which in turn decomposes back into hydrogen sulfide ions. The consumption of hydrogen sulfide ions is mainly in reactions with methoxyl groups forming mercaptane or in oxidation to thiosulfate and some organically bound sulfur (Lindfors et al. 1987).

Commonly it is recommended not to increase sulfidity above 50\% (approximately $0.3 \mathrm{~mol} / \mathrm{L}$ ) for softwood or above $35 \%$ (approximately $0.23 \mathrm{~mol} / \mathrm{L}$ ) for hardwood, as it is claimed that this would not increase delignification rate any further. However, it has been shown that increasing sulfidity above these recommended levels has indeed a positive effect on delignification rate. In a study by Olm et al. (2009) a beneficial effect was obtained on the delignification rate when increasing sulfidity up to $100 \%$. A certain kappa number can be reached in half the cooking time when pulping at $100 \%$ sulfidity $\left(\left[\mathrm{HS}^{-}\right]=1.22 \mathrm{M}\right)$ compared to a $35 \%$ sulfidity $\left(\left[\mathrm{HS}^{-}\right]=0.23 \mathrm{M}\right)$ for softwood. For hardwood, positive effects on delignification rate are reached up to $80 \%$ sulfidity (Olm et al. 2009). However, the recovery system for regeneration of cooking chemicals limits the 
industrially obtainable sulfidity level of the white liquor. The sulfidity or hydrogen sulphide ion concentration cannot be varied independently from the effective alkali charge, as can be seen in Fig. 6. At a certain effective alkali charge, sulfidity can be increased by utilizing black liquor.

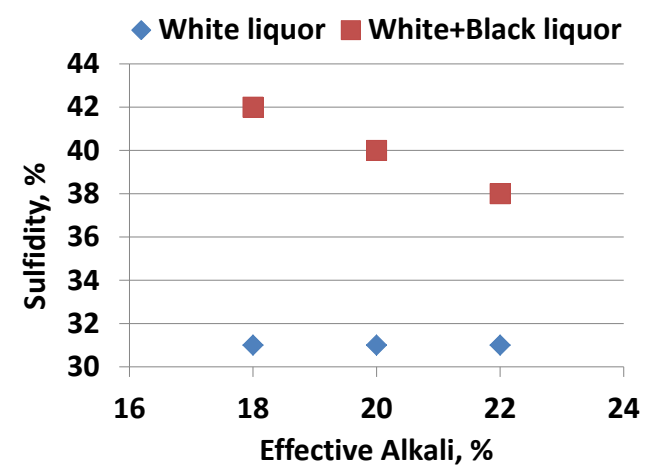

a)

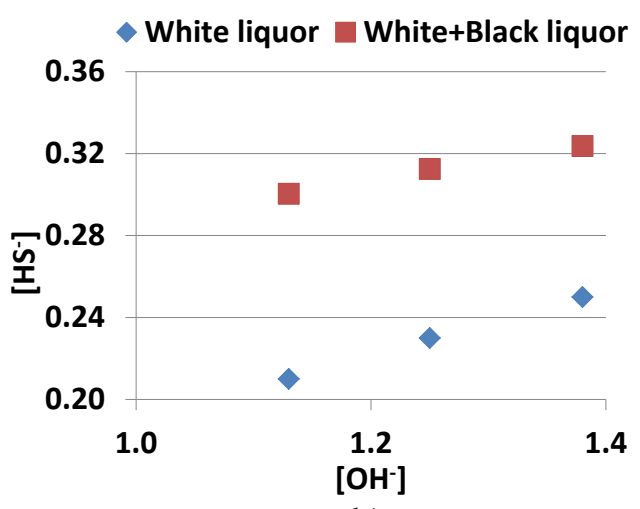

b)

Fig. 6. Effect on sulfidity and concentration of hydrogen sulfide and hydroxide ions, depending on the effective alkali charge. Calculations are made by the author and based on a white liquor with an effective alkali concentration of $110 \mathrm{~g} / \mathrm{L}$ and a sulfidity of $31 \%$, using standard definitions for effective alkali and sulfidity on $\mathrm{NaOH}$ basis (not $\mathrm{Na}_{2} \mathrm{O}$ ). The liquor-to-wood ratio is $4 \mathrm{~L} / \mathrm{kg}$, obtained either by diluting with water (the White liquor case) or with black liquor with a hydrogen sulfide concentration of approx. $0.28 \mathrm{~mol} / \mathrm{L}$ (White +Black liquor). The amount of residual alkali in the black liquor has not been included in the calculations.

Although the rate of bulk delignification can be increased when applying a sulfidity above the recommended level, the effect on the delignification rate in the residual phase of softwood kraft cooking is unaffected, and only a minor effect on the amount of lignin removed is obtained by highly increased sulfidity. According to results presented in Fig. 7, no additional removal of lignin is obtained by increasing the sulfidity above approximately 35\%. The data in Fig. 7a are based on constant cooking time, but as shown by Olm et al. (2009), the decrease in kappa number is very limited upon prolonged cooking time (Fig. 7b). For softwood (pine/spruce) the kappa number at which delignification levels off is at around 15 to 20.

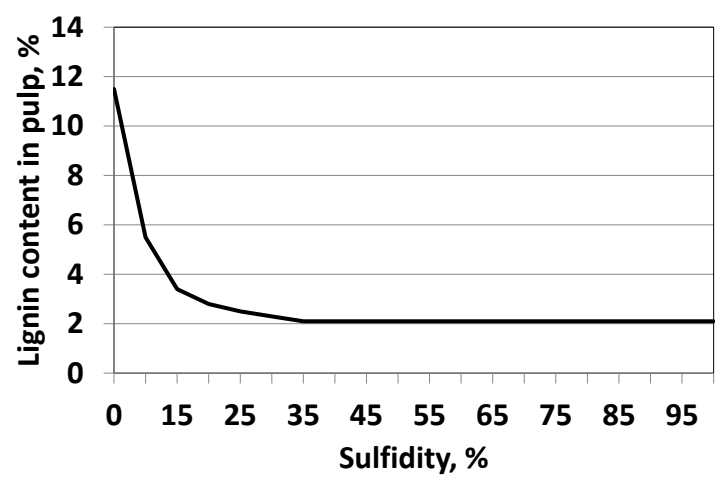

a)

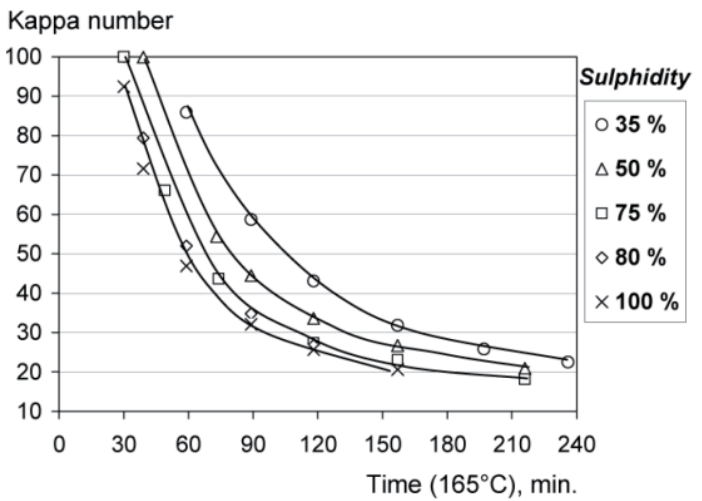

b)

Fig. 7. a) Data from Rydholm (1965). Cooking of Douglas fir at $170{ }^{\circ} \mathrm{C}$ for $1.5 \mathrm{~h}$ at an effective alkali charge of $20 \%$. b) Kraft cooking of softwood at an effective alkali of $19.5 \%$ at varied sulfidities (Olm et al. 2009) 
In the studies cited above, the pulping was performed at liquor-to-wood ratios normal to industrial pulping, i.e. approximately $4 \mathrm{~L} / \mathrm{kg}$ and at a certain charge of effective alkali. This means that as alkali is consumed, the concentration of hydroxide ions will decrease with cooking time. In research, the kinetics of kraft pulping have been studied by constant-composition cooking. By employing very high liquor-to-wood ratio, $70 \mathrm{~L} / \mathrm{kg}$ or more, the concentration of the active cooking chemicals is practically not affected although alkali is consumed in reactions with wood components. With unlimited access to hydroxide ions, as in constant-composition cooks, it would be possible to continue to obtain almost complete delignification of softwood although at a very low rate in the residual softwood delignification phase (Lindgren and Lindström 1996).

Increased sulfidity increases the bulk delignification rate also for hardwoods, but in the residual phase the delignification seems to come to a definite stop, approximately at a kappa number around 10 (Chai et al. 2001a; Monrroy et al. 2008). This is observed also in constant-composition cooks with unlimited access to alkali (Lindgren and Lindström 1997). However, prolonging the cooking time will actually result in some dissolution of lignin, but also in the continued formation of hexenuronic acid groups (Chai et al. 2001a). As these carbohydrate structures consume permanganate in the kappa number analysis, the effect seems to be a complete stop in the delignification. For birch kraft pulping at industrial liquor-to-wood levels, no further delignification below kappa number 14 is obtained (Olm et al. 2009).

The amount of residual phase lignin is decreased with increased [ $\mathrm{HS}^{-}$] for softwood (Lindgren and Lindström 1996), although the decrease is much smaller for hardwood (Lindgren and Lindström 1997).

\section{Effect of Hydroxide lon Concentration on Delignification}

Hydroxide ions deprotonate phenolic and aliphatic hydroxyl groups in lignin and also react by nucleophilic addition to the aliphatic part of lignin (Gierer 1982). Both reactions promote lignin fragmentation and lignin solubilization, making the hydroxide ion a vital part in the removal of lignin. There are certain bonds in lignin that are cleaved due to the presence of $\mathrm{OH}^{-}$, without the participation of hydrogen sulfide ions. These are $\alpha$-aryl ether bonds in phenolic units and $\beta$-aryl ether bonds in non-phenolic units. Also the cleavage of certain carbon-carbon bonds is alkali promoted (Gierer 1982).

The concentration of hydroxide ions has a large effect on the delignification rate (LeMon and Teder 1973; Nordén and Teder 1979; Johansson et al. 1984; Chiang et al. 1990), the effect being larger than the effect obtained by increased hydrogen sulfide ion concentration (Johansson et al. 1984; Chiang et al. 1990). Additionally, the amount of slow reacting residual phase lignin is significantly reduced at higher hydroxide ion concentrations (Lindgren and Lindström 1996; Gilarranz et al. 2002), probably because of the alkali promoted cleavage of carbon-carbon bonds and the positive effect on lignin solubility.

Alkali is consumed to a large extent during kraft cooking. As a rule of thumb, 1 ton of softwood chips consumes approximately 145 to $150 \mathrm{~kg}$ of $\mathrm{NaOH}$ during kraft cooking (Chiang et al. 1987), while the same quantity of hardwood chips consume 135 to $145 \mathrm{~kg}$ of $\mathrm{NaOH}$ (Chiang et al. 1987). As can be seen in Table 1, only a minor amount of the alkali is consumed in delignification reactions. It is important to charge a higher amount of alkali than what is consumed, as the $\mathrm{pH}$ needs to be kept at a sufficiently high level at the end of the cook, > pH 11, not to risk precipitation of dissolved lignin (Norgren et al. 2002). 
Table 1. Consumption of Alkali in Kraft Pulping (Chiang et al. 1987).

\begin{tabular}{|c|c|c|c|}
\hline & \multicolumn{3}{|c|}{ Consumption of effective alkali, kg/ton wood } \\
\hline Wood type & $\begin{array}{c}\text { Initially } \\
\text { (deacetylation) }\end{array}$ & $\begin{array}{c}\text { Neutralization of } \\
\text { carbohydrate } \\
\text { degradation } \\
\text { products }\end{array}$ & Delignification \\
\hline Softwood & $50(15)$ & 60 & 35 \\
\hline Hardwood & $75(35)$ & 30 & 30 \\
\hline
\end{tabular}

\section{Effect of lonic Strength on Delignification}

Industrial cooking liquors contain quite a high amount of various ions. Apart from sodium ions, the counter ions balancing the negative charge of hydroxide and hydrogen sulfide ions, sodium ions are also counter ions to carbonate and sulfate ions, resulting from incomplete reduction in the recovery furnace and incomplete caustization. Although hydrogen sulfide and hydroxide ions are the active cooking chemicals in normal kraft cooking, as they degrade and dissolve lignin, their counter ions and other positively charged ions are by no means inactive. It has been shown that at higher sodium ion concentration in the cooking liquor, i.e. at higher ionic strength, the rate of delignification is decreased (LeMon and Teder 1973; Johansson et al. 1984; Lindgren and Lindström 1996; Lundqvist et al. 2006; Bogren et al. 2007, 2009). The effect of ionic strength on delignification rate is not an actual decrease in chemical reaction rates, but rather an effect on lignin solubility (Dang et al. 2014, 2016a). Due to the Donnan effect, the concentration of sodium ions will be higher inside the fibre wall liquid compared to the bulk liquid. The higher concentration of cations has a negative effect on the solubility of lignin in the entrapped liquid. As a consequence, higher ionic strength will give an accumulation of lignin in the fibre wall, whereas a lower ionic strength would allow lignin to be leached out (Sixta et al. 2006; Dang et al. 2016a; 2016b). This can be an explanation for the increased amount of residual phase lignin at higher ionic strength (Lindgren and Lindström 1996, 1997). It has been shown that at higher ionic strength, the lignin has to be more degraded before it is dissolved (Dang et al. 2016a,b).

When performing kraft cooking studies to evaluate the effect of chemical charges on the cooking performance and pulp properties, it should be kept in mind that increasing either the hydrogen sulfide or hydroxide ion concentration also will increase the sodium ion concentration. The ionic strength is sometimes controlled in laboratory cooking by addition of $\mathrm{NaCl}$ or other salts. Using $\mathrm{Cl}^{-}$as the counter ion to sodium has a larger retarding effect on delignification rate compared to $\mathrm{SO}_{4}{ }^{2-}$ (Bogren et al. 2009). Chloride ions have a higher ability to precipitate lignin. Using $\mathrm{Na}_{2} \mathrm{CO}_{3}$ on the other hand can have a positive effect on delignification rate, particularly for hardwood cooking. The carbonate ions can react with calcium ions forming calcium carbonate precipitates (Lundqvist $e t a l$. 2006). The presence of $\mathrm{Ca}^{2+}$ in the cooking liquor retards delignification, as the solubility of lignin is impaired (Lundqvist et al. 2006).

\section{Effect of Temperature on Delignification}

As in all chemical reactions, an increase in temperature increases the rate of delignification, as illustrated in Fig 8a. The H-factor relates time and temperature into one single parameter, as can be seen in Fig 8b. The H-factor is based on the Arrhenius equation and uses the activation energy of bulk delignification of softwood. The use of $\mathrm{H}$-factors makes it possible to control the cooking time to reach a target kappa number. 
The H-factor was originally developed for softwood kraft cooking. However, the activation energy for bulk delignification is similar for both softwood and hardwood, which means the same $\mathrm{H}$-factor control can be used for hardwood kraft cooking (Santos et al. 2011).

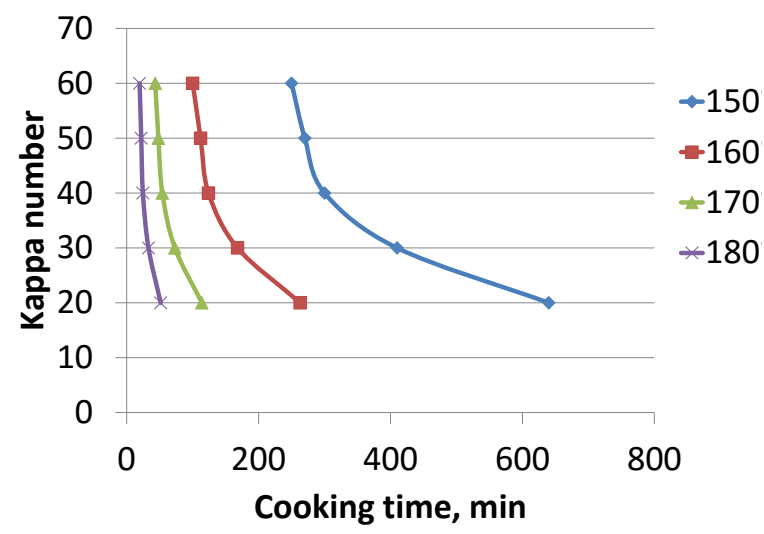

a)

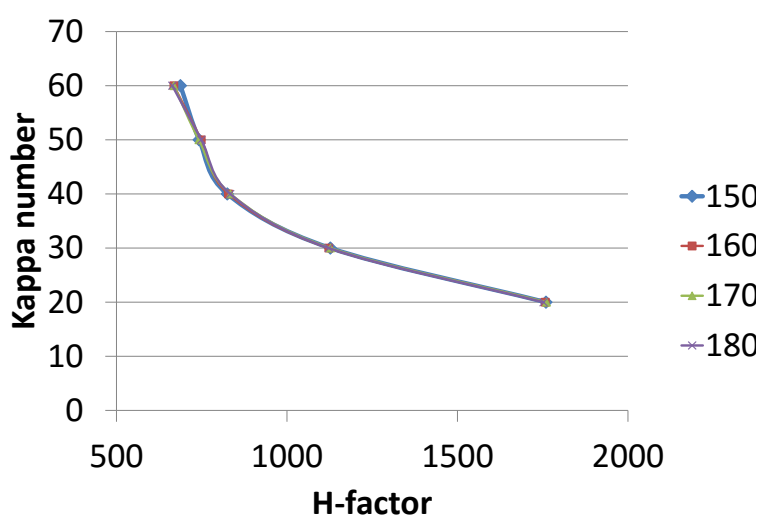

b)

Fig. 8. Delignification rate in kraft cooking of spruce with an effective alkali charge of $21 \%$ and $35 \%$ sulfidity at a liquor-to-wood ratio of $4 \mathrm{~L} / \mathrm{kg}$ wood. a) Kappa number of obtained pulp as function of cooking time. b) Kappa number of obtained pulp as a function of $\mathrm{H}$-factor

The amount of slow-reacting residual phase lignin is not affected by increased temperature in softwood kraft pulping (Chiang et al. 1990; Lindgren and Lindström 1997). However, increased temperature decreases the amount of residual phase lignin in kraft cooks of eucalyptus (Gilarranz et al. 2002; Lourenco et al. 2012; Almeida et al. 2015).

For long, $170{ }^{\circ} \mathrm{C}$ was regarded as the standard cooking temperature for softwood. With the development of modified kraft cooking and the discovery of the beneficial effect of low cooking temperatures on pulp yield and pulp viscosity, cooking temperatures were gradually decreased. Bulk delignification reactions start at $140{ }^{\circ} \mathrm{C}$, so apart from production rate, there is nothing preventing kraft pulping from being performed at such a low temperature. By elevating the effective alkali charge to very high level, the kraft cooking can be performed at $140{ }^{\circ} \mathrm{C}$ with a high delignification rate (Paananen and Sixta 2015).

\section{HOW MUCH LIGNIN CAN BE REMOVED IN THE KRAFT COOKING STAGE?}

As the process stages after pulping are numerous, the question arises - would it be possible to remove the remaining 3-7\% lignin in the cooking stage, if the pulping was performed at sufficiently high hydrogen sulfide concentration and temperature and with high charge of effective alkali? However, since the aim of the kraft cooking is to obtain pulp at high yield and high strength potential, this would not be economical, since too much of the carbohydrates would be lost as well. The rate of delignification slows down significantly when approximately $95 \%$ of the originally present lignin in wood has been removed. The rate of the reactions degrading and dissolving the carbohydrates, however, continues more or less unaffected. The limit for how much lignin that can be removed in kraft pulping is thus determined by the amount of slow reacting residual phase lignin and 
to what extent the carbohydrates are degraded and dissolved depending on the process parameters employed.

\section{Effect of Hydroxide Ion Concentration on Carbohydrate Reactions}

Hydroxide ions affect carbohydrates in a number of ways. The acetyl groups on xylan in hardwood and on glucomannan in softwood are cleaved off by hydroxide ions, releasing acetic acid. Deacetylation is a very rapid reaction, which consumes a large part of hydroxide ions in a kraft cook. Deacetylation is unavoidable in alkaline media and can be regarded as a wanted reaction. Deacetylation improves the accessibility of the wood matrix, thus improving the diffusion of cooking chemicals. Hardwoods have a higher amount of acetyl groups compared to softwood, $3 \%$ on wood compared to $1.5 \%$, respectively. Some types of extractives are saponified by alkali and dissolved into the cooking liquor. Carboxyl groups are deprotonated, and xylan, containing methylglucuronic acid groups, becomes soluble in the cooking liquor. Also pectic substances, having carboxylic groups, are easily soluble in alkali. The free phenolic groups in lignin are deprotonated. The creation of charged groups will lead to swelling of the fibre wall, also increasing the paths available for ionic movement.

Peeling of polysaccharides in alkali is a well-known reaction, causing the highest losses of carbohydrate yield. Alkali attacks the reducing end group in a carbohydrate polymer and peels off the terminating sugar unit, which is dissolved into the cooking liquor as an isosaccharinic acid. The new terminal sugar unit is transformed into a reducing end group, susceptible to attack by alkali, leading to continued peeling of the carbohydrate chain. The peeling reaction is prevented when it reaches the highly ordered crystalline areas of cellulose molecules or when the terminal sugar unit is substituted with an arabinose or uronic acid group, as in xylan. Peeling also ends when the terminal sugar unit is transformed to a more alkali-stable end group by the stopping reaction. Glucomannan, lacking the protection of crystalline areas and better leaving groups, is highly susceptible to peeling. As much as $70 \%$ of the glucomannan originally present in wood is practically immediately dissolved when in contact with alkali, the amount dissolved being more or less the same whether the alkali concentration is $0.3 \mathrm{M}$ or $1.3 \mathrm{M}$ (Wigell et al. 2007a; Paananen et al. 2010). The only saviour of glucomannan yield in ordinary kraft cooking is the stopping reaction. Contradictory as it may sound, increased glucomannan yield can be obtained by elevating the alkali concentration (Wigell et al. 2007b; Paananen et al. 2010; Paananen et al. 2013). The rate of the peeling reaction for glucomannan is increased with increasing hydroxide ion concentration up to $0.5 \mathrm{M}$. Above this level no further increase in peeling rate is obtained. The rate of the stopping reaction on the other hand continues to rise as hydroxide ion concentration increases (Lai and Ontto 1979). At a $\left[\mathrm{OH}^{-}\right]$of $1.55 \mathrm{M}$ the ratio between the stopping and peeling reactions is much more favorable, leading to a higher retention of glucomannan (Paananen et al. 2013; Nieminen et al. 2014), see Fig. 9. 


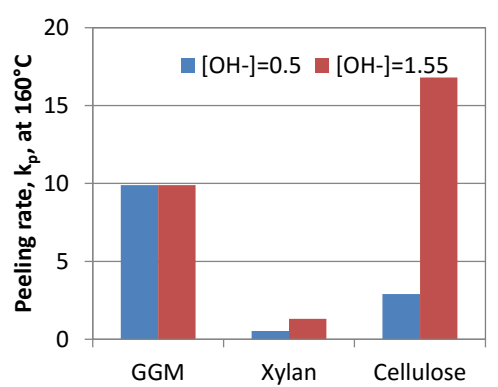

a)

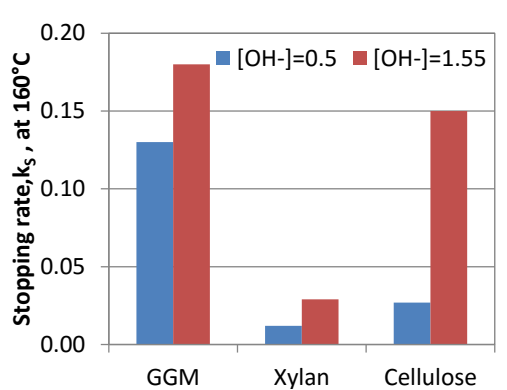

b)

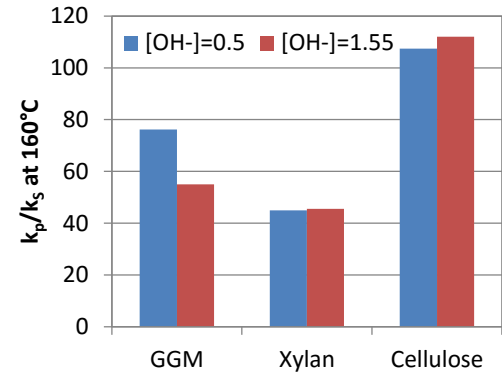

c)

Fig. 9. Reaction rates at $160^{\circ} \mathrm{C}$ for a) peeling, $\mathrm{k}_{\mathrm{p}}$, b) stopping, $\mathrm{k}_{\mathrm{s}}$, and $\mathrm{c}$ ) the ratio between peeling and stopping. Adapted from data in Nieminen et al. (2014).

Alkaline hydrolysis attacks randomly selected $\beta-\mathrm{O}-4$ linkages in the carbohydrate chains. This does not decrease yield but results in a reduction of the carbohydrate molecular weight. However, the cleavage of the $\beta-\mathrm{O}-4$ linkage has created a new reducing end group, which will be susceptible to the peeling reaction, now entitled secondary peeling. In the case of cellulose yield, secondary peeling has the largest effect (Johansson and Germgård 2008a; Nieminen et al. 2014). Alkaline hydrolysis is a rather slow reaction, requiring both high temperature and high alkali (Wigell et al. 2007b). However, the rate of alkaline hydrolysis is more affected by an increased alkali concentration than the rate of peeling, which means that the molecular weight of cellulose will be decreased to a larger extent than the yield upon increased alkali concentration (Johansson and Germgård 2008a; Nieminen et al. 2014). The rate of hydrolysis of the xylan molecule is much faster compared to hydrolysis of cellulose or glucomannan (Nieminen et al. 2014).

The loss of xylan from wood has a pronounced dependence on alkali concentration (Wigell et al. 2007a). It is mainly xylan lost in molecular form, as its glucuronic acid makes it soluble in alkali. The amount xylan dissolved is approximately 5 to 6 times higher than the amount of xylan lost due to peeling (Nieminen et al. 2014). Also in black liquor, the dissolved xylan is relatively stable. The uronic acid groups are cleaved off, while the molecular weight is only decreased to a smaller extent (Lisboa et al. 2005; Li Jansson and Brännvall 2011). Although eucalyptus xylan has a higher amount of methyl glucuronic acid groups, it is more stable compared to birch xylan (Pinto et al. 2005). One reason for the less soluble nature of eucalyptus xylan is the higher molecular weight (Pinto et al. 2005). Additionally, the uronic acid groups in eucalyptus xylan are substituted with galactose and glucose units (Shalatov et al. 1999; Evtuguin et al. 2003; Pinto et al. 2005). Primary peeling is not important for xylan; more xylan is dissolved than is degraded by peeling (Wigell et al. 2007a). If the alkalinity is above approximately $0.25 \mathrm{M}$, then less xylan is redeposited on the fibres, resulting in lower yield (Nieminen et al. 2014).

The hydroxide ion can also react with the methyl glucuronic group on the xylan chain to form a hexenuronic acid group (HexA) (Teleman et al. 1995). HexA is not present in wood but is formed during alkaline pulping. Alkali can also dissolve xylan and degrade the HexA, so as the cooking proceeds there will at first be an increase in the amount of HexA in the pulp fibres. At some point, the rate of dissolution and degradation rate of HexA becomes larger than the rate of formation. The cooking conditions determine the position at which the maximum HexA content in pulp is reached. Also the raw material affects the formation rate. In alkaline pulping of softwood, the formation 
rate of HexA is fast, and the maximum HexA content is reached already in the heating-up period of the cook (Chai et al. 2001b; Simao et al. 2005). For hardwoods, the formation rate is slow and the maximum HexA content is reached at the end of the cook (Chai et al. 2001b; Simao et al. 2005; Monrroy et al. 2008). The rate of formation of hexenuronic acid groups increases with increasing hydroxide ion concentration (Pedroso and Carvalho 2003; Simao et al. 2005).

The $\left[\mathrm{OH}^{-}\right]$ion concentration has a complicated relationship to carbohydrates. There is no simple relationship between change in $\left[\mathrm{OH}^{-}\right]$and effect on yield and viscosity. For example, on the one hand, increased $\left[\mathrm{OH}^{-}\right]$increases the dissolution of xylan and the rates of peeling and alkaline hydrolysis. On the other hand, it also increases delignification rate, thereby decreasing the time needed to reach a certain degree of delignification, which also means less time for carbohydrate degradation reactions to take place.

Very high $\left[\mathrm{OH}^{-}\right]$will generally lead to yield losses and decreased molecular weight of carbohydrates, but as mentioned earlier, very high $\left[\mathrm{OH}^{-}\right](1.55 \mathrm{M})$ promotes the stopping reaction and increases the amount of glucomannan retained (Paananen et al. 2010). The hemicelluloses composition of the pulp can be tailored by the alkalinity during pulping. By increasing alkali charge, the proportion of glucomannan will increase and the xylan fraction will decrease (Aurell and Hartler 1965; Brännvall and Lindström 2007a; Paananen et al. 2010).

A too low $\left[\mathrm{OH}^{-}\right]$value is detrimental as well for both yield and viscosity. If $\left[\mathrm{OH}^{-}\right]$ is decreased at some point in the cook to a very low concentration (below $0.2 \mathrm{M}$ ), this can result in decreased viscosity as well as lower yield (Andersson et al. 2003; Santiago et al. 2008), except if the concentration dip occurs at the final stage of cooking, when the decreased alkali concentration would promote xylan redeposition (Sjöblom et al. 1983a). A too low $\left[\mathrm{OH}^{-}\right]$can have a more severe effect on viscosity than too high $\left[\mathrm{OH}^{-}\right]$, since there is sufficient alkali for carbohydrate degradation to take place while the concentration is too low for delignification to occur and specifically for degraded lignin to be kept in solution (Johansson and Germgård 2008a).

\section{Effect of Temperature on Carbohydrate Reactions}

Increased temperature increases the loss of carbohydrates. The rate of the peeling reaction is prominent already at $70{ }^{\circ} \mathrm{C}$ and will increase with increasing temperature (Wigell et al. 2007a). For glucomannan, increased temperature hardly affects the rate of primary peeling, since this carbohydrate is so severely affected by this reaction (Nieminen et al. 2014). Increased temperature increases the rate of secondary peeling for all the wood carbohydrates (Nieminen et al. 2014).

The rate of alkaline hydrolysis is highly affected by temperature (Johansson et al. 1984). It is prominent already at $140{ }^{\circ} \mathrm{C}$, and increased temperature will affect the alkaline hydrolysis rate to a larger extent than the rate of delignification (Johansson et al. 1984). Performing pulping at lower temperature is therefore more selective in terms of pulp viscosity at a given kappa number (Jiang et al. 1992; Bäckström et al. 1996). For high yield and high pulp viscosity, cooking temperatures of $150{ }^{\circ} \mathrm{C}$ for hardwoods are recommended (Dang and Nguyen 2007). Also the yield is improved by lowering the temperature, as the rate of the peeling reaction is decreased as well (Nieminen et al. 2014). The effect of increased temperature is most pronounced for the cellulose yield as increased rate of alkaline hydrolysis will lead to increased amount of secondary peeling (Johansson and Germgård 2008b). The number of glucose units removed by secondary 
peeling is much higher compared to primary peeling (da Silva Perez and van Heiningen 2015).

For xylan, higher cooking temperatures cause several detrimental effects. Besides increased rate of alkaline hydrolysis and peeling, the protective effect of uronic acid substituents is decreased at higher temperatures (Nieminen et al. 2014). Increasing the temperature leads to increased dissolution of xylan (Wigell et al. 2007a). Additionally, increasing cooking temperature increases the rate of hexenuronic acid formation (Pedroso and Carvalho 2003), which starts at $110{ }^{\circ} \mathrm{C}$ (Simao et al. 2005). Lower cooking temperature has a positive effect on the xylan yield (Brännvall and Lindström 2007a).

\section{Effect of lonic Strength on Carbohydrate Reactions}

Increased concentration of sodium ions in the cooking liquors affects the various carbohydrates somewhat differently. The dissolution of xylan and glucomannan are decreased when ionic strength is increased (Dang et al. 2014), whereas the dissolution of cellulose is increased (Brännvall and Lindström 2007b; Johansson and Germgård 2008a). Alkaline hydrolysis does not seem to be affected by the ionic strength (Johansson and Germgård 2008a). The molecular weight of cellulose molecules is not affected by the ionic strength during cooking according to Johansson and Germgård (2008a), whereas Brännvall and Lindström (2007b) report a decrease in degree of polymerization of cellulose. Pulp viscosity is undoubtedly decreased at higher sodium ion concentration (Sjöblom et al. 1983a). Partly this can be an effect of more cellulose dissolved in combination with more hemicelluloses retained. The average molecular weight of carbohydrates in pulp is decreased because of higher retention of short chained hemicelluloses.

\section{Effect of Hydrogen Sulfide Ion Concentration on Carbohydrate Reactions}

Although no reactions occur between hydrogen sulfide ions and carbohydrates, the $\left[\mathrm{HS}^{-}\right]$still has a large effect on pulp yield and pulp viscosity. Since [HS $\left.{ }^{-}\right]$profoundly affects the delignification rate, increased $\left[\mathrm{HS}^{-}\right]$leads to shorter cooking times to reach a given degree of delignification and thereby also shorter time for carbohydrate degradation reactions to occur. High $\left[\mathrm{HS}^{-}\right]$is of most importance initially in the cook and during bulk delignification (Sjöblom et al. 1983a).

It has been reported that increased [HS $\left.{ }^{-}\right]$has a slight effect on dissolution of xylan (Bogren et al. 2007; Johansson and Germgård 2008b) and glucomannan (Johansson and Germgard 2008). It was hypothesized that the hemicelluloses might be dissolved together with lignin fragments.

\section{Modified Kraft Cooking - A Way to Prolong Delignification in the Pulping Stage}

From the discussions above, it can be concluded that to reach lower levels of residual lignin contents in the pulp after kraft cooking, increasing [ $\mathrm{HS}^{-}$] is of no avail in the case of softwood cooking, whereas increasing [ $\left.\mathrm{HO}^{-}\right]$will make it possible to push the limit of delignification further. Too keep the ionic strength at as low level as possible is also beneficial in terms of increasing the degree of delignification.

In the 1980's much effort within pulp research was exerted in order to find selective process conditions enabling more lignin to be removed during the pulping stage. The driving force behind so-called extended or prolonged cooking was the formation of chlorinated aromatic structures during bleaching. The amount of these environmentally 
hazardous compounds formed correlates strongly with the amount of lignin in the pulp to be bleached (Nordén and Teder 1979; Sjöblom et al. 1983b; Bergnor et al. 1988; Andrews 1989). In order to reduce the levels of chlorinated compounds in the effluents from pulp mills, the aim was to reduce the kappa number of the pulp entering the first chlorine bleaching stage.

The research on extended delignification in the cooking stage led to modifications of the kraft process, hence called modified kraft cooking. The modifications consisted of changes of the alkali profile during pulping, leveling out the concentration more evenly through the cook by multiple addition points of white liquor in contrast to the conventional kraft cooking where all effective alkali is charged initially (Carnö and Hartler 1976). The concept of modified cooking also involves lower cooking temperatures compared to the level of $170{ }^{\circ} \mathrm{C}$ normally employed previously (Jiang et al. 1992), high hydrogen sulfide ion concentration in the initial and bulk delignification and lowering the concentration of dissolved wood components in the cooking liquor. The aim of the modified kraft cooking however was not to obtain complete delignification, only to extend the delignification from the kappa number levels of 30 to 35 down to 12 to 15 for softwood (George et al. 2000). Much attention in the research on extended delignification was directed to selectivity in terms of pulp viscosity at a given kappa number. Leveled out alkali profile, lower cooking temperature, higher hydrogen sulfide concentration, and lower concentration of dissolved wood components all lead to higher pulp viscosity at a given kappa number. The pulp yield on the other hand is not lower at a given kappa number (Sjöblom, et al. 1983b; Johansson et al. 1984; Teder and Sandström 1985; Bäckström and Jensen 2001). Extending the delignification to lower kappa numbers invariably leads to lower pulp yield (Sjöblom et al. 1983b).

Extending cooking to very low kappa numbers also means that the delignification kinetics are dominated by the slow residual phase delignification. The residual phase lignin is more resistant to delignification, as its structure is more complex with increased amount of carbon-carbon bonds. There is some debate as to whether the increase of these structures is due to lignin condensation reactions taking place during pulping (Gellerstedt et al. 2004) or if it a result of an accumulation of condensed structures by attrition (Balakshin et al. 2003).

Presently, the benefits of higher selectivity obtained in the pulping stage by modified kraft pulping are not used for prolonging the cooking stage but by terminating the kraft cook at a kappa number of 27 to 32 for bleachable softwood pulp and 15 to 20 for hardwood pulp and prolong the delignification in the oxygen stage (Nordén and Teder 1979). This combines the effects of higher pulp viscosity achieved by modified kraft pulping with the lower yield loss in oxygen delignification.

\section{Lignin-Carbohydrate Linkages and Delignification}

The chemical components in wood are interconnected with each other through chemical bonds, forming a crosslinked polymer network. In pulp, 90\% of residual lignin is covalently bound to carbohydrates (Lawoko et al. 2004). The linkages exist almost entirely (>90\%) between hemicelluloses and lignin (Lawoko et al. 2003). These linkages have been proposed to be the reason why delignification cannot be extended without simultaneous dissolution of carbohydrates. The close relation between lignin and carbohydrates can be seen by the fact that delignification and removal of hemicelluloses show a linear correlation (Wigell et al. 2007a; Santos et al. 2012). Xylan removal has a strong correlation with the amount of lignin removed (Wigell et al. 2007a). Glucomannan 
is initially very rapidly degraded by primary peeling but subsequently a slower degradation follows, which is linearly proportional to removal of lignin (Wigell et al. 2007a).

In softwood, the lignin-carbohydrate linkages seem to be quite equally divided between xylan-lignin networks and glucomannan-lignin networks (Lawoko et al. 2003). The xylan-lignin networks are easier to remove than the glucomannan-lignin networks, while lignin-galactoglucomannan complexes are quite resistant to alkali (Iwata et al. 1998). Consequently, in unbleached softwood pulp, most of the lignin-carbohydrate linkages in the residual lignin are comprised of glucomannan-lignin complexes (Kosikova and Erbringerova 1994; Lawoko et al. 2004) with significant amounts of galactose and arabinose (Balakshin et al. 2003, 2011). In hardwoods, the residual lignin is linked to xylan (Tenkanen et al. 1999; Balakshin et al. 2003; Ibarra et al. 2007). It is suggested that pectic substances play an important role in the linkages between lignin and hemicelluloses (Balakshin et al. 2007, 2011).

\section{SUMMARY AND CONCLUSIONS}

The limits of delignification between the least amount of lignin necessary to remove, while still obtaining chemically liberated fibres, and the highest amount possible, without high carbohydrate losses, are quite narrow. In general, for softwood, more than $80 \%$ of the originally present lignin needs to be removed to reach the point of fibre liberation and the degree of delignification should not exceed 95\%. For hardwood, the boundaries are even more limited. The least needed to reach the defibration point is around $90 \%$ of the lignin originally present in wood and the highest around $95 \%$.

A thorough impregnation is essential in order to decrease the degree of delignification needed to obtain fibre liberation. In industrial practice, the defibration point is defined by the amount of shives in the pulp, originating from undelignified parts of the chip interior. Cooking needs to continue until a sufficiently low reject amount is reached, usually to a shives content of $1 \%$ on wood. A thorough impregnation reduces the area within wood chips having insufficient access to cooking chemicals and ensures that all parts of the chips are homogeneously delignified, thus decreasing the amount of shives and enabling the delignification to be terminated at a higher kappa number.

The simultaneous degradation and dissolution of carbohydrates limits the amount of lignin that can be removed in the kraft cooking stage. As the lignin remaining in the delignified chips mainly consists of the slow reacting residual phase lignin, the selectivity towards delignification is too low for continued cooking. In Table 2, the effects of conditions during kraft pulping on the bulk delignification and amount of residual phase lignin are summarized. The amount of resistant residual phase lignin is reduced by higher levels of hydroxide and lower amounts of dead load in the white liquor. 
Table 2. Summary of Effects on Delignification

\begin{tabular}{|c|c|c|}
\hline Effect of increased & Bulk delignification rate & Amount of residual phase lignin \\
\hline$\left[\mathrm{HS}^{-}\right]$ & $\begin{array}{c}\text { Increased rate } \\
\text { Large effect }>0-0.1 \mathrm{M} \\
\text { Less effect }>0.1 \mathrm{M}\end{array}$ & $\begin{array}{c}\text { Lower for SW } \\
\text { Slightly lower for HW }\end{array}$ \\
\hline$\left[\mathrm{OH}^{-}\right]$ & Increased rate, large effect & Lower \\
\hline lonic strength & Decreased rate & Higher amount \\
\hline Temperature & Increased rate, large effect & $\begin{array}{c}\text { No effect SW } \\
\text { Lower amount HW }\end{array}$ \\
\hline S/G ratio & Increased rate & No effect \\
\hline
\end{tabular}

The carbohydrate yield can be preserved by limiting the extent of peeling. In kraft cooking without carbohydrate preserving additives, this means reducing the extent of secondary peeling, as this is the main cause for carbohydrate losses. The effects of process conditions on carbohydrate reactions are summarized in Table 3.

A low cooking temperature decreases the rate of alkaline hydrolysis, which initiates secondary peeling. Also higher alkali concentration leads to increased carbohydrate dissolution. However, as higher alkalinity is beneficial for lignin degradation and dissolution a lower temperature is recommended rather than decreasing alkalinity.

Table 3. Summary of Effects on Carbohydrate Reactions

\begin{tabular}{|c|c|c|c|c|c|}
\hline $\begin{array}{c}\text { Effect of } \\
\text { increased }\end{array}$ & Hydrolysis & Peeling & Cellulose & Xylan & Glucomannan \\
\hline [HS-] & No effect & No effect & No effect & $\begin{array}{l}\text { Slightly } \\
\text { increased } \\
\text { removal }\end{array}$ & $\begin{array}{l}\text { Slightly } \\
\text { increased } \\
\text { removal }\end{array}$ \\
\hline$\left[\mathrm{OH}^{-}\right]$ & Increased rate & $\begin{array}{l}\text { Increased } \\
\text { rate up to } \\
0.5 \mathrm{M}\end{array}$ & $\begin{array}{l}\text { Increased } \\
\text { degradation }\end{array}$ & $\begin{array}{l}\text { Increased } \\
\text { dissolution, } \\
\text { pronounced } \\
\text { effect }\end{array}$ & $\begin{array}{c}\text { No effect up to } \\
0.5 \mathrm{M} \\
\\
\text { At elevated } \\
{\left[\mathrm{OH}^{-}\right] \text {, less }} \\
\text { degradation }\end{array}$ \\
\hline Ionic strength & Increased rate & $\begin{array}{l}\text { Increased } \\
\text { secondary } \\
\text { peeling }\end{array}$ & $\begin{array}{l}\text { Increased } \\
\text { degradation }\end{array}$ & $\begin{array}{l}\text { Less } \\
\text { dissolution }\end{array}$ & $\begin{array}{l}\text { Increased } \\
\text { degradation }\end{array}$ \\
\hline Temperature & $\begin{array}{l}\text { Increased rate } \\
\text { pronounced } \\
\text { effect }\end{array}$ & $\begin{array}{l}\text { Pronounced } \\
\text { effect on } \\
\text { extent of } \\
\text { secondary } \\
\text { peeling }\end{array}$ & $\begin{array}{l}\text { Increased } \\
\text { degradation }\end{array}$ & $\begin{array}{l}\text { Increased } \\
\text { dissolution, } \\
\text { pronounced } \\
\text { effect }\end{array}$ & $\begin{array}{l}\text { Increased } \\
\text { degradation } \\
\text { and dissolution }\end{array}$ \\
\hline S/G ratio & No effect & No effect & No effect & $\begin{array}{l}\text { Increased rate } \\
\text { of dissolution }\end{array}$ & No effect \\
\hline
\end{tabular}

The hydrogen sulfide concentration has no direct effect on carbohydrate reactions, but indirectly it is vital for a high carbohydrate yield. Hydrogen sulfide ions degrade 
lignin efficiently, reducing the pulping time to reach a certain degree of delignification and thus reducing the time for carbohydrate degradation. However, as xylan is closely linked to lignin, increased lignin dissolution may have an effect on xylan yield as well, as can be seen by increasing xylan dissolution by increased hydrogen sulfide ion concentration and higher $\mathrm{S} / \mathrm{G}$ ratio.

\section{ACKNOWLEDGMENTS}

Marie Bäckström and Fernando Alvarado are gratefully acknowledged for valuable comments on the manuscript.

\section{REFERENCES CITED}

Ahlgren, P., Yean, W., and Goring, D. (1971). "Chlorite delignification of spruce wood. Comparison of the molecular weight of the lignin dissolved with the size of pores in the cell wall," Tappi 54(5), 737-740.

Ahlgren, P., and Olausson, J. (1973). "Vapour phase kraft cooking. Part II. Pulp properties," Svensk Papperstidn. 76(16), 592-596.

Almeida, D., Santos, R., Hart, P., and Jameel, H. (2015). "Hardwood pulping kinetics of bulk and residual phases," Tappi J. 14(10), 652-662.

Andersson, N., Wilson, D., and Germgård, U. (2003). "Model-based kraft cooking optimization,” Nord. Pulp Paper Res. J. 18(4), 446-454. DOI: 10.3183/NPPRJ-200318-04-p446-454

Andrews, E. (1989). "RDH kraft pulping to extend delignification, decrease effluent and improve productivity and pulp properties," Tappi J. 72(11), 55-61.

Aurell, R. (1963). "Några jämförande synpunkter på sulfatkokning av tall- och björkved," Svensk Papperstidn. 66(23), 978-989.

Aurell, R., and Hartler, N. (1965). "Kraft pulping of pine. II. Influence of the charge of alkalio on the yield, carbohydrate composition, and properties of the pulp," Svensk Papperstidn. 68(4), 97-102.

Bäckström, M., Hägglund, M., and Olm, L. (1996). "Effect of cooking temperature during extended delignification - Selectivity, strength properties and TCFbleachability," Paperi Puи 78(6-7), 392-397.

Bäckström, M., and Jensen, A. (2001). "Modified kraft pulping to high kappa numbers," Appita 54(2), 203-209.

Balakshin, M., Capanema, E., Chen, C., and Gracz, H. (2003). "Elucidation of the structures of residual and dissolved pine kraft lignins using an HMQC NMR technique," J. Agric. Food Chem. 51, 6116-6127. DOI: 10.1021/jf034372d

Balakshin, M., Capanema, E., and Chang, H. (2007). "MWL fraction with a high concentration of lignin-carbohydrate linkages: Isolation and 2D NMR spectroscopic analysis," Holzforschung 61(1), 1-7. DOI: 10.1515/HF.2007.001

Balakshin, M., Capanema, E., Gracz, H., Chang, H., and Jameel, H. (2011). "Quantification of lignin-carbohydrate linkages with high resolution NMR spectroscopy," Planta 233(6), 1097-1110. DOI: 10.1007/s00425-011-1359-2 
Bergnor, E., Sandström, P., and Sjöblom, K. (1988). "Modified cooking and oxygen bleaching for improved production economy and reduced effluent load," Nord. Pulp Paper Res. J. 3(3), 145-151, 155. DOI: 10.3183/NPPRJ-1988-03-03-p145-152

Bogren, J., Brelid, H., and Theliander, H. (2007). "Reaction kinetics of softwood kraft delignification - General considerations and experimental data," Nord. Pulp Paper Res. J. 22(2), 177-183. DOI: 10.3183/NPPRJ-2007-22-02-p177-183

Bogren, J., Brelid, H., Bialik, M., and Theliander, M. (2009). "Impact of dissolved sodium salts on kraft cooking reactions," Holzforschung 63(2), 226-231. DOI: 10.1515/HF.2009.032

Brännvall, E., and Lindström, M. (2007a). "The hemicellulose composition of pulp fibres and their ability to endure mechanical treatment," Tappi J. 6(10), 19-24.

Brännvall, E., and Lindström, M. (2007b). "The impact of ionic strength during kraft cooking on the strength properties of softwood pulp," Appita J. 60(1), 60-64.

Carnö, B., and Hartler, N. (1976). "Kraft pulping to low kappa numbers," Stockholm: STFI.

Chai, X., Luo, Q., Yoon, S., and Zhu, J. (2001a). "The fate of hexenuronic acid groups during kraft pulping of hardwoods," J. Pulp Paper Sci. 27(12), 403-406.

Chai, X., Yoon, S., Zhu, J., and Li, J. (2001b). "The fate of hexenuronic acid groups during alkaline pulping of loblolly pine,” J. Pulp Paper Sci. 27(12), 407-411.

Chang, H., and Sarkanen, K. (1973). "Species variation in lignin. Effect of species on the rate of kraft delignification," Tappi 56(3), 132-134.

Chiang, V., Cho, H., Puumala, R., Eckert, R., and Fuller, W. (1987). "Alkali consumption during kraft pulping of Douglas fir, western hemlock, and red alder,” Tappi 2, 101104.

Chiang, V., Stoke, D., and Funaoka, M. (1989). "Lignin fragmentation and condensation reactions in middle lamellae and secondary wall regions during kraft pulping of douglas fir," J. Wood Chem. Technol. 9(1), 61-83.

Chiang, V., and Funaoka, M. (1990). "The dissolution and condensation reactions of guaiacyl and syringyl units in residual lignin during kraft delignification of sweetgum," Holzforschung 44(2), 147-155.

Chiang, V., Yu, J., and Eckert, R. (1990). "Isothermal reaction kinetics of kraft delignification of Douglas-fir," J. Wood Chem. Technol. 10(3), 293-310.

Colodette, J., and Borges Gomes, F. (2014). "A novel approach for maximizing eucalypt kraft pulp yield and bleachability," J-FOR 4(5), 38-44.

Coté, W. (1981). "Ultrastructure - Critical domain for wood behaviour. Its origins, current concepts, future potential," Wood Sci. Technol. 15(1), 1-29.

da Silva Perez, D., and van Heiningen, A. (2015). "Prediction of alkaline pulping yield: Equation derivation and validation," Cellulose 22(6), 3967-3979. DOI: $10.1007 / \mathrm{s} 10570-015-0735-7$

Dang, V., and Nguyen, K. (2007). "A systematic approach for determination of optimal conditions for Lo-Solids ${ }^{\mathrm{TM}}$ kraft pulping of Eucalyptus nitens," Chem. Eng. J. 133(1), 97-103. DOI: 10.1016/j.cej.2007.02.012

Dang, V., and Nguyen, K. (2008). "A universal kinetic model for characterisation of the effect of chip thickness on kraft pulping," Biores. Technol. 99(5), 1486-1490. DOI: 10.1016/j.biortech.2007.02.034 
Dang, B., Brelid, H., Köhnke, T., and Theliander, H. (2014). "Effect of sodium ion concentration profile during softwood kraft pulping on delignification rate, xylan retention and reactions of hexenuronic acids," Nord. Pulp Paper Res. J. 29(4), 604611. DOI: 10.3183/NPPRJ-2014-29-04-p604-611

Dang, B., Brelid, H., and Theliander, H. (2016a). "The impact of ionic strength on the molecular weight distribution (MWD) of lignin dissolved during softwood kraft cooking in a flow-through reactor," Holzforschung 70(6), 495-501. DOI: 10.1515/hf2015-0103

Dang, B., Brelid, H., and Theliander, H. (2016b). "What do we know regarding the kinetics of delignification in kraft cooking?," Autrans, France, $14^{\text {th }}$ European Workshop on Lignocellulosics and Pulp, pp. 5-8.

Evtuguin, D., Tomás, J., Silva, A., and Neto, P. (2003). "Characterization of an acetylated heteroxylan from Eucalyptus globulus Labill," Carbohyd. Res. 338, 597607. DOI: 10.1016/S0008-6215(02)00529-3

Fengel, D., and Wegener, G. (1984). Wood - Chemistry, Ultrastructure, Reactions, Walter de Gruyter, Berlin and New York.

Fergus, B., and Goring, A. (1969). "The topochemistry of delignification in kraft and neutral sulphite pulping of birch wood," Pulp Paper Mag. Can. Sept, 65-73 (T314T322).

Fergus, B., and Goring, D. (1970). "The location of guaiacyl and syringyl lignins in birch xylem tissue," Holzforschung 24(4), 113-117.

Gellerstedt, G., Majtnerova, A., and Zhang, L. (2004). "Towards a new concept of lignin condensation in kraft pulping. Initial results," Comptes Rendus Biologies 327, 817826. DOI: 10.1016/j.crvi.2004.03.011

George, J., Lachenal, D., and Robert, D. (2000). "Application of the principles of extended delignification: Effects on softwood kraft residual lignin," J. Pulp Paper Sci. 26(8), 271-274.

Gierer, J. (1980). "On the course of delignification during kraft pulping," Holzforschung 34(6), 197-200.

Gierer, J. (1982). "The chemistry of delignification. A general concept," Holzforschung 36(1), 43-51.

Gilarranz, M., Santos, A., García, J., Oliet, M., and Rodriguez, F. (2002). “Kraft pulping kinetics of Eucalyptus globulus: Kinetics of residual delignification," Ind. Eng. Chem. Res. 41(8), 1955-1959. DOI: 10.1021/ie0108907

Gullichsen, J., Kolehmainen, H., and Sundqvist, H. (1992). "On the nonuniformity of the kraft cook," Paperi Puu 74(6), 486-490.

Gullichsen, J., Hyvärinen, R., and Sundqvist, H. (1995). "On the nonuniformity of the kraft cook. Part 2," Paperi Puu, 77(5), 331-337.

Hardell, H., Leary, G., Stoll, M., and Westermark, U. (1980). "Variations in lignin structure in defined morphological parts of spruce," Svensk Papperstidn. 83(2), 4449.

Hart, J., and Strapp, R. (1948). “Alkaline pulping -spruce," Pulp Paper Mag. Can. Convention issue, 151-165.

Hartler, N., and Östberg, K. (1959). "Impregneringen vid sulfatkoket," Svensk Papperstidn. 62(15), 524-533. 
Hartler, N., and Onisko, W. (1962). "The interdependence of chip thickness, cooking temperature, and screening in kraft type cooking of pine," Svensk Papperstidn. 65, 905-910.

Hultholm, T. (2004) "Impregnation behaviour of the active ions in the kraft process," Åbo: Åbo Akademi University.

Ibarra, D., Chavez, M., Rencoret, J., del Rio, J., Gutierrez, A., Romero, J., Camarero, S., Martinez, M., Jimenez-Barbero, J., and Martinez, A. (2007). "Lignin modification during Eucalyptus globulus kraft pulping followed by totally chlorine-free bleaching: A two dimensional nuclear magnetic resonance, Fourier transform infrared, and pyrolysis-gas chromatography/mass spectrometry study," J. Agr. Food Chem. 55, 3477-3490.

Inalbon, M., and Zanuttini, M. (2008). "Dynamics of the effective capillary crosssectional area during the alkaline impregnation of eucalyptus wood," Holzforschung 62(4), 397-401. DOI: 10.1515/HF.2008.061

Inalbon, M., Mocchiutti, P., and Zanuttini, M. (2009a). "The deacetylation reaction in Eucalyptus wood: Kinetics and effects on the effective diffusion," Biores. Technol. 100, 2254-2258. DOI: 10.1016/j.biortech.2008.10.054

Inalbon, M., Mussati, M., and Zanuttini, M. (2009b). "Experimental and theoretical analysis of the alkali impregnation of eucalyptus wood," Ind. Eng. Chem. Res. 48(10), 4791-4795. DOI: 10.1021/ie801685a

Inalbon, M., Mussati, M., Mocchiutti, P., and Zanuttini, M. (2011). "Modeling of alkali impregnation of eucalyptus wood," Ind. Eng. Chem. Res. 50(5), 2898-2904. DOI: 10.1021/ie1019408

Iwata, T., Indrati, L., and Azuma, J. (1998). "Affinity of hemicellulose for cellulose produced by Acetobacter xylinium," Cellulose 5(3), 215-228. DOI: 10.1023/A:1009237401548

Jiang, J., Greenwood, B., Phillips, J., and Becker, E. (1992). "Extended delignification with a prolonged mild counter-current cooking stage," Appita 45(1), 19-22.

Johansson, B., Mjöberg, J., Sandström, P., and Teder, A. (1984). "Modified continuous kraft pulping - Now a reality," Svensk Papperstidn. 87(10), 30-35.

Johansson, D., and Germgård, U. (2008a). "Carbohydrate degradation during softwood kraft cooking - Influence on cellulose viscosity, carbohydrate composition and hexenuronic acid content," Nord. Pulp Paper Res. J. 23(3), 292-298. DOI: 10.3183/NPPRJ-2008-23-03-p292-298

Johansson, D., and Germgård, U. (2008b). "A kinetic study of softwood kraft cooking Carbohydrate dissolution as a function of the cooking conditions," Appita 61(3), 228233.

Kerr, A., and Goring, D. (1976). "Kraft pulping of pressure-refined fibres. Reactivity of exposed middle lamellae lignin," Svensk Papperstidn. 79(1), 20-23.

Kleinert, T. (1964). "Rapid alkaline pulping,” Pulp Paper Mag. Can. July, T275-T283.

Kohn, R., and Kovac, P. (1978). "Dissociation constants of D-galacturonic and Dglucuronic acid and their $O$-methyl derivatives," Chem. Zvesti 32(4), 478-485.

Kolar, J., Lindgren, B., and Treiber, E. (1982). "The distribution of lignin between fiber wall and middle lamellae," Svensk Papperstidn. 85(3), R21-R26.

Kosikova, B., and Erbringerova, A. (1994). "Lignin-carbohydrate bonds in residual soda spruce pulp lignin,” Wood Sci. Technol. 28(4), 291-296. 
Lai, Y., and Ontto, E. (1979) "Effects of alkalinity on endwise depolymerization of hydrocellulose," J. Appl. Polym. Sci. 23, 3219-3225. DOI: 10.1002/app.1979.070231107

Laine, J., Lövgren, L., Stenius, P., and Sjöberg, S. (1994). "Potentiometric titration of unbleached kraft cellulose fibre surfaces," Colloids Surfaces 88, 277-287. DOI: 10.1016/0927-7757(94)02834-6

Lawoko, M., Henriksson, G., and Gellerstedt, G. (2003). "New method for the quantitative preparation of lignin-carbohydrate complex from unbleached softwood kraft pulp: Lignin-polysaccharide networks I," Holzforschung 57(1), 69-74. DOI: 10.1515/HF.2003.011

Lawoko, M., Berggren, R., Berthold, F., Henriksson, G., and Gellerstedt, G. (2004). "Changes in the lignin carbohydrate complex of softwood during kraft and oxygen delignification: Lignin-polysaccharide networks II," Holzforschung 58(6), 603-610. DOI: $10.1515 /$ HF.2004.114

Legg, G., and Hart, J. (1960). “Alkaline pulping of Jack pine and Douglas fir. The influence of sulphide and effective alkali charge on pulping rate and pulp properties," Pulp Paper Mag Can. 61(5), T299-T304.

LeMon, S., and Teder, A. (1973). "Kinetics of the delignification in kraft pulping. I. Bulk delignification of pine," Svensk Papperstidn. 76(11), 407-414.

Liitiä, T., Maunu, S., and Hortling, B. (2000). "Solid-state NMR studies of residual lignin and its association with carbohydrates," J. Pulp Paper Sci. 29(9), 323-330.

Li Jansson, Z., and Brännvall, E. (2011). "Characterisation of dissolved spruce xylan in kraft cooking," Nord. Pulp Paper Res. J. 26(4), 380-385. DOI:

10.3183/NPPRJ-2011-26-04-p380-385

Lindfors, E.-L., Gellerstedt, G., Teder, A., and Tormund, D. (1987). "The distribution of different sulfur compounds in kraft cooking,” Paris, Int. Symp. Wood Pulp Chem., pp. 167-170.

Lindgren, C., and Lindström, M. (1996). "The kinetics of residual delignification and factors affecting the amount of residual lignin during kraft pulping," J. Pulp Paper Sci. 22(8), J290-J295.

Lindgren, C., and Lindström, M. (1997). "Kinetics of bulk and residual delignification in kraft pulping of birch and factors affecting the amount of residual phase lignin," Nord. Pulp Paper Res. J. 12(2), 124-127. DOI: 10.3183/NPPRJ-1997-12-02-p124127

Lisboa, S., Evtuguin, D., Neto, P., and Goodfellow, B. (2005). "Isolation and structural characterization of polysaccharides dissolved in Eucalyptus globulus kraft black liquors," Carbohyd. Polym. 60, 77-85. DOI: 10.1016/j.carbpol.2004.11.024

Lourenco, A., Gominho, G., Velez Marques, A., and Pereira, H. (2012). "Reactivity of syringyl and guaiacyl lignin units and delignification kinetics in the kraft pulping of Eucalyptus globulus wood using Py-GC-MS/FID," Biores. Technol. 123, 296-302. DOI: 10.1016/j.biortech.2012.07.092

Lundqvist, F., Olm, L., and Tormund, D. (2006). "Effects of carbonate on delignification of birch wood in kraft cooking," Nord. Pulp Paper Res. J. 21(3), 290-296. DOI: 10.3183/NPPRJ-2006-21-03-p290-296

Malkov, S., Tikka, P., and Gullichsen, J. (2002). "Towards complete impregnation of wood chips with aqueous solutions Part 4. Effects of front-end modifications in displacement batch kraft pulping," Paperi Puu 84(8), 526-530. 
Malkov, S., Tikka, P., Gustafson, R., and Nuopponen, M. (2003). “Towards complete impregnation of wood chips with aqueous solutions. Part 5: Improving uniformity of kraft displacement batch pulping," Paperi Puu 85(4), 215-220.

Monrroy, M., Mendonca, R., Rodríguez, J., Baeza, J., and Freer, J. (2008). “Effect of pulping conditions on the amount of methylglucuronic and hexenuronic acids in kraft pulps of Eucalyptus globulus," Appita J. 61(3), 212-215.

Montagna, P., Inalbon, C., Paananen, M., Sixta, H., and Zanuttini, M. (2013). 'Diffusion dynamics in Pinus sylvestris kraft impregnation. Effects of deacetylation and galactoglucomannan degradation," Ind. Eng. Chem. Res. 52(10), 3658-3662. DOI: http://dx.doi.org/10.1021/ie3024388

Nieminen, K., Paananen, M., and Sixta, H. (2014). "Kinetic model for carbohydrate degradation and dissolution during kraft pulping," Ind. Eng. Chem. Res. 53(28), 11292-11302. DOI: 10.1021/ie501359p

Nordén, S., and Teder, A. (1979). "Modified kraft processes for softwood bleached-grade pulp," Tappi 62(7), 49-51.

Norgren, M., Edlund, H., Wågberg, L., and Annergren, G. (2002). "Fundamental physical aspects on lignin dissolution,” Nord. Pulp Paper Res. J. 17(4), 370-373.

Norgren, M., and Lindström, B. (2000). "Dissociation of phenolic groups in kraft lignin at elevated temperatures," Holzforschung 54(5), 519-527. DOI: 10.1515/HF.2000.088

Olm, L., Tormund, D., and Lundqvist, F. (2009). "High sulfidity kraft pulping," Nord. Pulp Paper Res. J. 24(4), 433-439. DOI: 10.3183/NPPRJ-2009-24-04-p433-439

Paananen, M., Tamminen, T., Nieminen, K., and Sixta, H. (2010) "Galactoglucomannan stabilization during the intitial kraft cooking of Scots pine," Holzforschung 64(6), 683-692. DOI: 10.1515/hf.2010.109

Paananen, M., Liitiä, T., and Sixta, H. (2013). "Further insight into carbohydrate degradation and dissolution behavior during kraft cooking under elevated alkalinity without and in the presence of anthraquinone," Ind. Eng. Chem. Res. 52(36), 12777127841. DOI: $10.1021 /$ ie 4018012

Paananen, M., and Sixta, H. (2015). "High-alkali low-temperature polysulfide pulping (HALT) of Scots pine," Bioresour. Technol. 193, 97-102. DOI: 10.1016/j.biortech.2015.06.075

Pedroso, A., and Carvalho, M. (2003). "Alkaline pulping of Portuguese Eucalyptus globulus: Effect on hexenuronic acid content," J. Pulp Paper Sci. 29(5), 150-154.

Pennings, A., and Prins, W. (1962). "The polyelectrolytic nature of cellulose gels in alkali solution," J. Polym. Sci. 58, 229-248. DOI: 10.1002/pol.1962.1205816613

Pinto, P., Evtuguin, D. V., and Neto, P. (2005). "Structure of hardwood glucuronoxylans: Modifications and impact on pulp retention during kraft pulping," Carbohyd. Polym. 60, 489-497. DOI: 10.1016/j.carbpol.2005.03.001

Procter, A., Yean, W., and Goring, D. (1967). "The topochemistry of delignification in kraft and sulphite pulping of spruce wood," Pulp Paper Mag. Can. 68(9), T445-T460.

Ragnar, M., Lindgren, C., and Nilvebrant, N. (2000). "pKa-values of guaiacyl and syringyl phenols related to lignin," J. Wood Chem. Technol. 20(3), 277-305.

Read, D., Wong, P., and Eade, B. (1969) "The penetration of Western hemlock wood with kraft white liquor," Pulp Paper Mag. Can., Sept, 80-85.

Reza, M., Kontturi, E., Jääskeläinen, A. S., Vuorinen, T., and Ruokolainen, J. (2015). "Transmission electron microscopy for wood and fiber analysis - A review," BioResources 10(3), 6230-6261. DOI: 10.15376/biores.10.3. 
Rydholm, S. (1965). "Part II. Preparation of unbleached pulp. Chemical pulping," Pulping Processes, New York - London - Sydney: Interscience Publishers, pp. 576649.

Sainio, M. (2000) “Optimizing birch chips for kraft pulp cooking,” Paperi Puu, 82(2), 103-107.

Saka, S., Thomas, R., Gratzl, J., and Abson, D. (1982) "Topochemistry of delignification in Douglas-fir wood with soda, soda-anthraquinone and kraft pulping as determined by SEM-EDXA," Wood Sci. Technol. 16(2), 139-153.

Saka, S., Hosoya, S., and Goring, D. (1983). "The distribution of lignin in hardwood as determined by bromination with TEM-EDXA," Kyoto, Int. Symp. Wood Pulping Chem., pp. 24-29.

Saka, S. (2000). "Chemical composition and distribution," Wood and Cellulosic Chemistry, $2^{\text {nd }}$ Ed., New York: Marcel Dekker, pp. 69-71.

Santiago, A., Neto, P., and Vilela, C. (2008) "Impact of effective alkali and sulfide profiling on Eucalyptus globulus kraft pulping. Selectivity of the impregnation phase and its effect on final pulping results," J. Chem. Technol. Biotechnol. 83, 242-251. DOI: 10.1002/jctb.1799

Santos, R., Capanema, E., Balakshin, M., Chang, H., and Jameel, H. (2011). "Effect of hardwoods characteristics on kraft pulping process: Emphasis on lignin structure," BioResources 6(4), 3623-3637. DOI: 10.15376/biores.6.4.3623-3637.

Santos, R., Jameel, H., Chang, H., and Hart, P. (2012). "Kinetics of hardwood carbohydrate degradation during kraft pulp cooking," Ind. Eng. Chem. Res. 51(38), 12192-12198. DOI: 10.1021/ie301071n

Saric, S., and Schofield, R. (1946). "The dissociation constants of carboxyl and hydroxyl groups in some insoluble and sol-forming polysaccharides," Proceed. Royal Society London A: Mathematical, Physical Eng. Sci. 185(1003) 431-447.

Sarkanen, K. (1971) Lignins: Occurrence, Formation, Structures and Reactions, New York: Wiley Interscience.

Shalatov, A., Evtuguin, D., and Neto, P. (1999). “(2-O-(-D-Galactopyranosyl-4-Omethyl-(-D-glucurono)-D-xylan from Eucalyptus globulus Labill," Carbohyd. Res. 320, 93-100. DOI: 10.1016/S0008-6215(99)

Simao, J., Egas, A., Baptista, C., Carvalho, G., and Castro, J. (2005). "Evolution of methylglucuronic and hexenuronic acid contents of Eucalyptus globulus pulp during kraft delignification," Ind. Eng. Chem. Res. 44(9), 2990-2996. DOI: 10.1021/ie049062e

Sixta, H., Rutkowska, E., Schröder, P., and Wollboldt, P. (2006). "Modeling of Eucalyptus globulus kraft pulping," Lenzing AG Process Innovation, 1-7.

Sjöblom, K., Mjöberg, J., and Hartler, N. (1983a). "Extended delignification in kraft cooking through improved selectivity. Part 1 . The effects of inorganic composition of the cooking liquor," Paperi Puu, 65(4), 227-240.

Sjöblom, K., Hartler, N., Mjöberg, J., and Sjödin, L. (1983b). “A new technique for pulping to low kappa numbers in batch pulping: Results of mill trials," Tappi J. 66(9), 97-102.

Sjöström, E., Janson, J., Haglund, P., and Enström, B. (1965). "The acidic groups in wood and pulp as measured by ion exchange," J. Polym. Sci. Part C 11, 221-241.

Teder, A., and Sandström, P. (1985). "Pulp yield in continuous kraft pulping with a modified alkali profile," Tappi J. 68(1), 94-95. 
Teleman, A., Harjunpää, V., Tenkanen, M., Buchert, J., Hausalo, T., Drakenberg, T., and Vuorinen, T. (1995). "Characterisation of 4-deoxy- $\beta$-1-threo-hex-4-enopyranosyluronic acid attached to xylan in pine kraft pulp and pulping liquor by ${ }^{1} \mathrm{H}$ and ${ }^{13} \mathrm{C}$ NMR spectroscopy," Carbohyd. Res. 272, 55-71. DOI: 10.1016/00086215(95)96873-M

Tenkanen, M., Tamminen, T., and Hortling, B. (1999). "Investigation of lignincarbohydrate complexes in kraft pulps by selective enzymatic treatments," Appl. Microbiol. Biotechnol. 51, 241-248. DOI: 10.1007/s002530051388

Tikka, P., and Kovasin, K. (1990). "Displacement vs. conventional batch kraft pulping: Delignification patterns and pulp strength delivery," Paperi Puи 72(8), 773-779.

Tolonen, L., Hiltunen, E., Helttunen, J., and Sixta, H. (2010). "Effects of impregnation time on hardwood kraft pulp characteristics and papermaking potential," Tappi J. 9(4), 21-27.

Tyler, D., and Edwards, L. (1982). "Predicting rejects from kraft cooking of overthick chips. A model incorporating caustic diffusion with delignification kinetics," Svensk Papperstidn. 85(18), R180-R184.

Wardrop, A. (1963). "Morphological factors involved in the pulping and beating wood fibres," Svensk Papperstidn. 66(7), 231-247.

Wardrop, A., and Davies, G. (1961). "Morphological factors relating to the penetration of liquids into wood," Holzforschung 15(5), 129-141.

Wedin, H., Lindström, M. E., and Ragnar, M. (2010). "Extended impregnation in the kraft cook - An approach to improve overall yield in eucalypt pulping," Nord. Pulp Paper Res. J., 25(1), 7-14.

Whiting, P., and Goring, D. (1982). "Relative reactivities of middle lamellae and secondary wall lignin of black spruce wood," Holzforschung 36(6), 303-306.

Wigell, A., Brelid, H., and Theliander, H. (2007a). "Degradation/dissolution of softwood hemicellulose during alkaline cooking at different temperatures and alkali concentration," Nord. Pulp Paper Res. J. 22(4), 488-494. DOI: 10.3183/NPPRJ2007-22-04-p488-494

Wigell, A., Brelid, H., and Theliander, H. (2007b). "Kinetic modelling of (galacto) glucomannan degradation during alkaline cooking of softwood," Nord. Pulp Paper Res. J. 22(4), 495-499. DOI: 10.3183/NPPRJ-2007-22-04-p495-499

Wood, J., Ahlgren, P., and Goring, D. (1972). "Topochemistry in the chlorite delignification of spruce wood," Svensk Papperstidn. 75(1), 15-19.

Yang, J., and Goring, D. (1978). "A comparison of the concentration of free phenolic hydroxyl groups in the secondary wall and middle lamellae regions of softwood," Pulp Paper Can. 79, T2-5.

Zanuttini, M., Citroni, M., Martinez, M., and Marzocchi, V. (1998). "Chemimechanical pulping of poplar wood: Alkaline wood pretreatment at low temperature," Holzforschung 52(4), 405-409. DOI: 10.1515/hfsg.1998.52.4.405

Zanuttini, M., Citroni, M., and Marzocchi, V. (2000). "Pattern of alkali impregnation of poplar wood at moderate conditions," Holzforschung 54(6), 631-636. DOI: 10.1515/HF.2000.106

Zanuttini, M., Marzocchi, V., Citroni, M., and Mocchiutti, P. (2003). "Alkali impregnation of hardwoods. Part I: Moderate treatment of poplar wood," J. Pulp Paper Sci. 29(9), 313-317. 
Zanuttini, M., Citroni, M., Marzocchi, V., and Inalbon, C. (2005). “Alkali impregnation ofhardwood chips," Tappi J. 4(2), 28-30.

Article submitted: November 10, 2016; Peer review completed: November 25, 2016;

Revised version received and accepted: January 9, 2016; Published: January 23, 2017.

DOI: 10.15376/biores.12.1.Brannvall 